\title{
Analysis Design of Ex-Service Garter Spring Irradiation Capsules in the High Flux Isotope Reactor
}

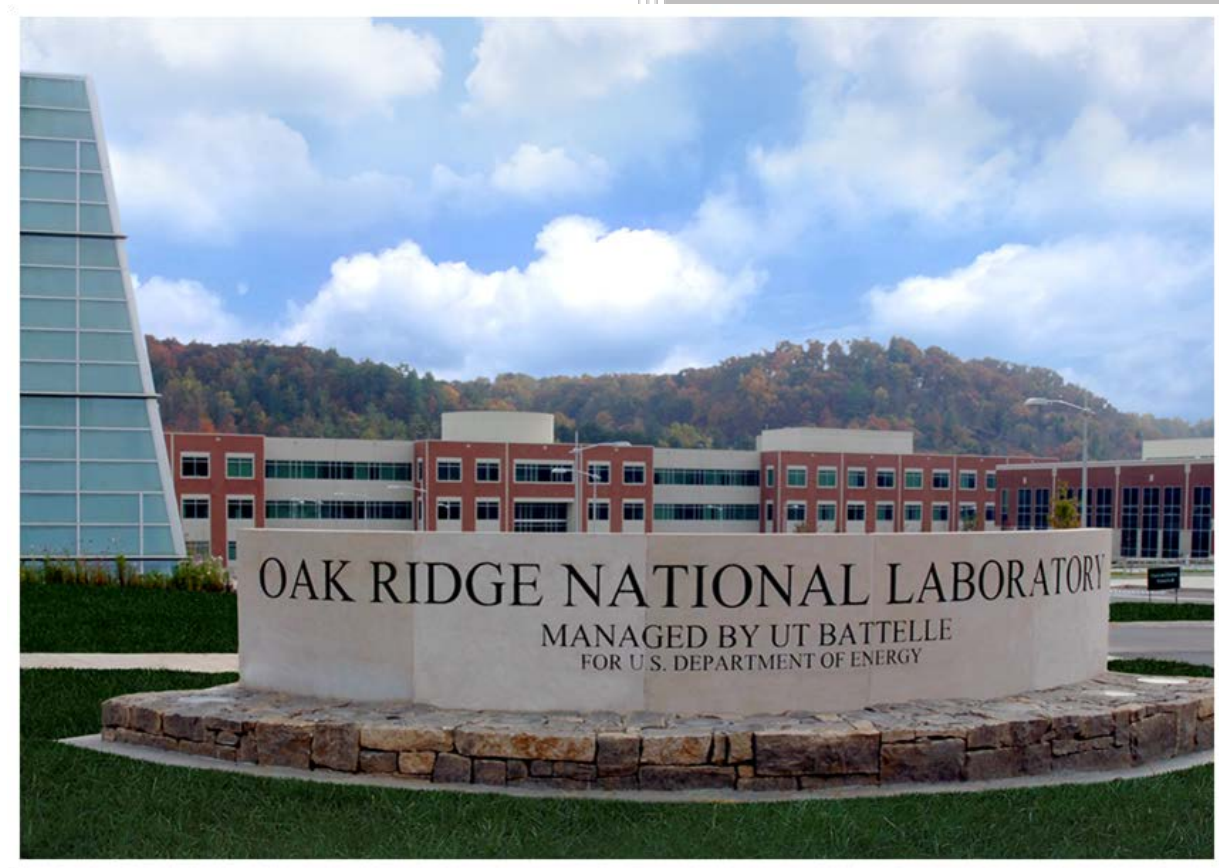

Approved for public release. Distribution is unlimited.

Ryan C. Gallagher Richard H. Howard Kurt R. Smith

Date: September 2018 


\title{
DOCUMENT AVAILABILITY
}

Reports produced after January 1, 1996, are generally available free via US Department of Energy (DOE) SciTech Connect.

\section{Website http://www.osti.gov/scitech/}

Reports produced before January 1, 1996, may be purchased by members of the public from the following source:

\author{
National Technical Information Service \\ 5285 Port Royal Road \\ Springfield, VA 22161 \\ Telephone 703-605-6000 (1-800-553-6847) \\ TDD 703-487-4639 \\ Fax 703-605-6900 \\ E-mail info@ntis.gov \\ Website http://classic.ntis.gov/
}

Reports are available to DOE employees, DOE contractors, Energy Technology Data Exchange representatives, and International Nuclear Information System representatives from the following source:

Office of Scientific and Technical Information

PO Box 62

Oak Ridge, TN 37831

Telephone 865-576-8401

Fax 865-576-5728

E-mail reports@osti.gov

Website http://www.osti.gov/contact.html

This report was prepared as an account of work sponsored by an agency of the United States Government. Neither the United States Government nor any agency thereof, nor any of their employees, makes any warranty, express or implied, or assumes any legal liability or responsibility for the accuracy, completeness, or usefulness of any information, apparatus, product, or process disclosed, or represents that its use would not infringe privately owned rights. Reference herein to any specific commercial product, process, or service by trade name, trademark, manufacturer, or otherwise, does not necessarily constitute or imply its endorsement, recommendation, or favoring by the United States Government or any agency thereof. The views and opinions of authors expressed herein do not necessarily state or reflect those of the United States Government or any agency thereof. 
Reactor and Nuclear Systems Division

\title{
ANALYSIS DESIGN OF EX-SERVICE GARTER SPRING IRRADIATION CAPSULES IN THE HIGH FLUX ISOTOPE REACTOR
}

\author{
Ryan C. Gallagher \\ Richard H. Howard \\ Kurt Smith
}

Date Published: September 2018

Prepared by

OAK RIDGE NATIONAL LABORATORY

Oak Ridge, TN 37831-6283

managed by

UT-BATTELLE, LLC

for the

US DEPARTMENT OF ENERGY

under contract DE-AC05-00OR22725 



\section{CONTENTS}

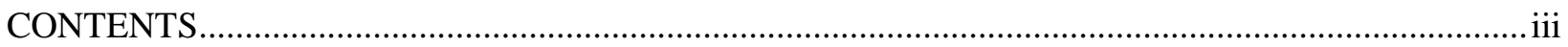

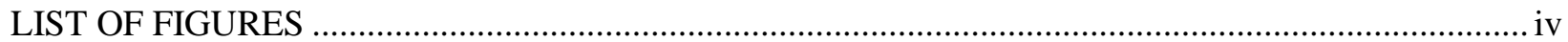

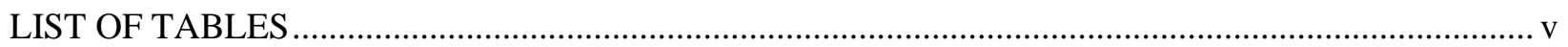

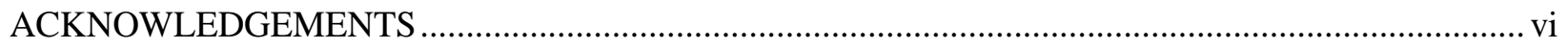

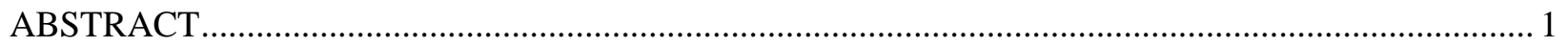

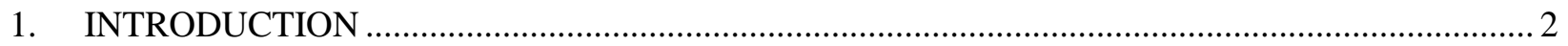

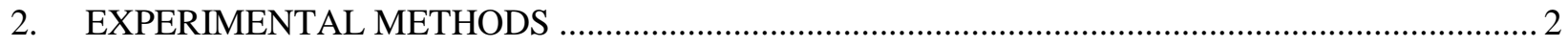

2.1 CAPSULE DESIGN .................................................................................................. 2

2.1.1 HFIR Irradiation and Experiment Design Concept.................................................... 2

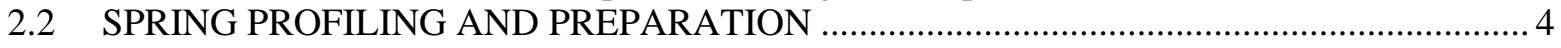

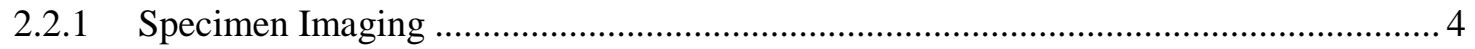

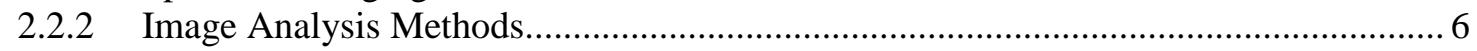

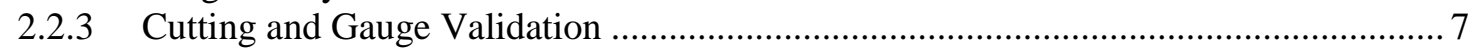

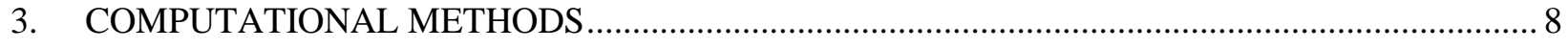

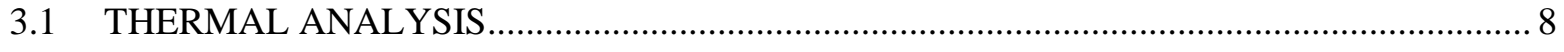

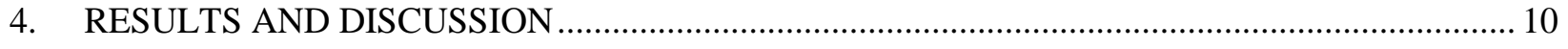

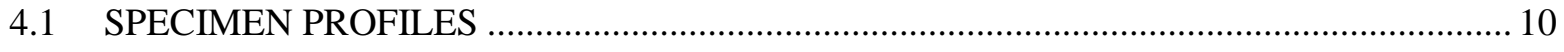

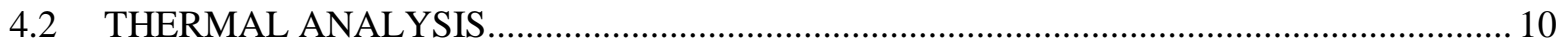

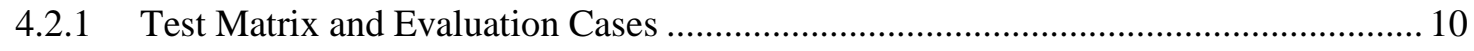

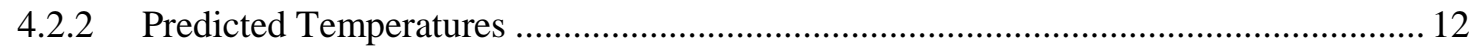

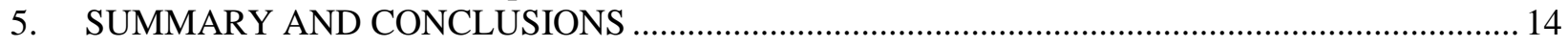

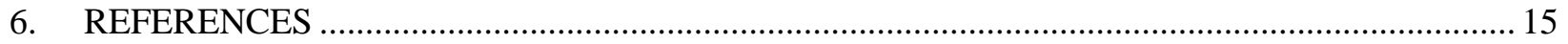

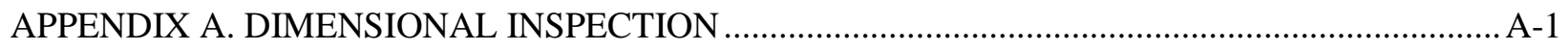

APPENDIX B. ANSYS CAPSULE DESIGN REPORTS ….......................................................... 


\section{LIST OF FIGURES}

Figure 1. Section views showing irradiation capsule design concept and CAD representation of the specimen.

Figure 2. 3D printed platform (left) and assembled motorized stage (right). ......................................... 5

Figure 3. Schematic diagram of specimen profiling setup in the hot cell............................................... 5

Figure 4. Garter spring specimen with emphasis on the bowing feature due to being wrapped around an operating pressure tube.

Figure 5. Measured coil data merged to show diametrical taper (pinched region corresponds to data sets 4 and 5; see APPENDIX A for raw data).

Figure 6. Low-speed saw cutting of a garter spring sample to remove a flared coil.

Figure 7. Rate theory calculations of Inconel X-750 volumetric swelling at varying dose and temperatures [15]

Figure 8. Partial section view of meshed 3D thermal finite element model ............................................ 10

Figure 9. Temperature contours $\left({ }^{\circ} \mathrm{C}\right)$ for a rabbit assembly (left) and specimen (right)............................ 13 


\section{LIST OF TABLES}

Table 1. Summary of the experiment assembly and part detail drawings............................................... 4

Table 2. Experiment materials and material property references........................................................... 9

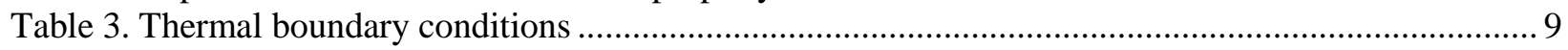

Table 4. Irradiation test matrix, design temperature, buffer dimensions, and holder dimensions .............. 11

Table 5. Predicted specimen temperatures for each capsule at BOI and EOI.......................................... 12

Table 6. Predicted passive temperature monitor (TM) temperatures for each rabbit at the BOI and

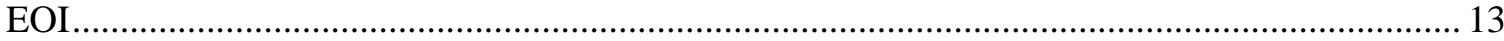




\section{ACKNOWLEDGEMENTS}

This research was performed at the Oak Ridge National Laboratory (ORNL) and sponsored by Canadian Nuclear Laboratories under the Materials Science and Technology Division, Strategic Partnership Program (SPP), IAN: 16B696401, and DOE agreement: NFE-13-04680 with the U.S. Department of Energy. Oak Ridge National Laboratory is managed by UT-Battelle, LLC under Contract No. DE-AC0500OR22725 for the U.S. Department of Energy.”

The authors would like to acknowledge the sponsors of this work. The multi-organizational group, which is led by the CANDU Owners Group, has provided the opportunity and funding for this exciting work. The technical representation for the sponsor was led by a Canadian Nuclear Laboratories, whose expertise and collaboration made the completion of the irradiation capsule design successful. Specifically, Grant Bickel and Rob DeAbreu were exceedingly helpful over the course of the project. The authors also acknowledge ORNL contributors, Wilna Geringer and Keith Leonard, who also afforded excellent guidance, management, and technical expertise. 


\begin{abstract}
Nickel-based super alloys such as Inconel X-750 are used to fabricate internal components for various reactor systems. Recent efforts to research and understand the effects of long-term neutron radiation damage on this material are crucial for quantifying the performance (radiation-induced creep and embrittlement) of such materials under extended use. The CANDU ${ }^{\circledR}$ ex-service garter spring irradiation program was instituted to investigate such effects on various types of Inconel X-750 garter springs, tensile specimens, and fatigue specimens. Conventional irradiation programs use rabbits, which are capsules that are generally loaded with nonradioactive irradiation specimens. These rabbits are designed to realize various specimen temperatures while irradiated to high neutron fluences in the Oak Ridge National Laboratory (ORNL) High Flux Isotope Reactor (HFIR). To accelerate the irradiation schedule of this program, two types of material — unirradiated and previously irradiated ex-service garter spring material-were both included in the irradiation program test matrix. These two material conditions are expected to provide intermediate and end-of-life neutron dose experimental results concurrently to accelerate the overall irradiation program schedule. This document describes the B8J18 garter spring design and the supporting work required to successfully fabricate, assemble, and qualify subsequent irradiation capsules.
\end{abstract}




\section{INTRODUCTION}

Nickel-based super alloys such as Inconel X-750 are used to fabricate internal components for various reactor systems. Recent efforts to research and understand the effects of long-term neutron radiation damage on this material are crucial for quantifying the performance (radiation induced creep and embrittlement) of such materials under extended use [1]. The CANDUß ex-service garter spring irradiation program was instituted to investigate such effects on various types of Inconel X-750 garter springs, tensile specimens, and fatigue specimens. Conventional irradiation programs use rabbits, which are capsules loaded with nonradioactive irradiation specimens. These rabbits are designed to reach various temperatures while irradiated to high neutron fluences in the Oak Ridge National Laboratory (ORNL) High Flux Isotope Reactor (HFIR). To accelerate the irradiation schedule of this program, two types of material—unirradiated and ex-service garter spring material—were both included in the original irradiation program test matrix. These two material conditions are expected to provide intermediate and end-of-life neutron dose experimental results concurrently to accelerate the overall irradiation program schedule.

While this approach will reduce the overall irradiation time by eliminating the need to take unirradiated material to the full end-of-life neutron dose, the plan to use ex-service materials comes with some significant challenges. The current irradiation project requires encapsulation of ex-service non-optimized garter springs. Since this material was previously irradiated in a commercial CANDUß reactor, it was

necessary to devise an appropriate irradiation design format and a method for assembling rabbit capsules in a heavily shielded hot cell environment. The primary hot cell remote interface is the master-slave manipulator system, which has its own set of challenges and limitations. Therefore, a flexible, reliable encapsulation infrastructure was designed and implemented to allow remote assembly, welding, and testing of rabbit capsules with radioactive specimens. This document describes the B8J18 garter spring design and the supporting work required to successfully fabricate, assemble, and qualify subsequent irradiation capsules.

\section{EXPERIMENTAL METHODS}

\subsection{CAPSULE DESIGN}

\subsubsection{HFIR Irradiation and Experiment Design Concept}

\subsubsection{HFIR Irradiation}

The High Flux Isotope Reactor (HFIR) is a beryllium-reflected, pressurized, light water-cooled and moderated flux trap-type reactor located at the Oak Ridge National Laboratory (ORNL) [2]. The core contains two involute-shaped plate type fuel elements that utilizes highly enriched ${ }^{235} \mathrm{U}$ fuel maintain a steady state power level of $85 \mathrm{MW}$. The flux trap region houses three irradiation facilities: the peripheral target position (PTP) facility, target rod rabbit holder (TRRH) facility, and the hydraulic tube facility (HT). In these facilities, the most common irradiation experiments consist of small, un-instrumented "rabbit" capsules, which is the experiment format detailed in this work. The HFIR flux profile is not uniform in the axial direction, and each position generally has unique power level. As such, these positions are numbered in increasing order from the bottom to the top for the flux trap irradiation facilities. Positions TRRH-4 and PTP-5 are closest to the reactor's midplane. 
This document describes the design of HFIR-approved irradiation capsules to contain sections of exservice Inconel X-750 garter spring spacers used in CANDU reactors. Neutron and gamma radiation from HFIR fuel cause heating of the experiment materials, while the experiment is cooled by the reactor coolant. The heating rates are taken from neutronic models of the HFIR core and were provided as inputs to thermal finite element models. The thermal models are used to ensure that specimen temperature targets during irradiation are met, since there is no active monitoring of the thermal performance in-situ. Passive silicon carbide (SiC) temperature monitors, or thermometry, are used to validate the irradiation temperature predictions post-irradiation [3]. Typically, experiment designs use a small insulating gas gap as the primary method for temperature control of the specimens. The size of the gap and the choice of the fill gas (typically helium, neon, or argon) inside the experiment are chosen so that the heat generated in the experimental components that passes through the gas gap gives the desired temperature drop across the gap. The temperature drop is a function of the heat flux through the gap, the thermal conductivity of the fill gas, and the size of the gas gap.

\subsubsection{Experiment Design Concept}

The overall design of the irradiation experiments developed in this work is shown in Figure 1. Design drawings of the experiment assembly and part details are summarized in Table 1 . The irradiation capsule containment (also referred to as the housing) is fabricated from a stainless steel-to-aluminum transition joint to facilitate hot cell welding [4] and is in direct contact with the HFIR primary coolant. The capsule subassembly is situated within an Al-6061 holder. Moving radially inward, the subassembly includes a zirconium dioxide $\left(\mathrm{ZrO}_{2}\right)$ buffer, the Inconel X-750 garter spring specimens, and an $\mathrm{Al} 6061$ insert that contains a SiC passive temperature monitor. The size of the gas-gap between the holder and inner wall of the housing provides the primary means of temperature control. Tabs of raised material on the outer diameter of the holder center the holder concentrically in the housing so the appropriate gap is maintained throughout the entire irradiation. Two titanium alloy endcaps are threaded into both ends of the holder to secure the specimen axially. The $\mathrm{ZrO}_{2}$ buffer is press fit into the heated holder during assembly to ensure that no extraneous gas gap occurs between the buffer and the holder from differential thermal expansion during irradiation. The specimen-to-buffer gas gap and the buffer thickness provide an additional mode of temperature control and insulate the spring specimens from large thermal gradients.

For designs focused on reaching temperatures as low as achievable during irradiation, no gas-gaps between the holder and the housing are necessary. These cold capsule designs will feature a thick-walled housing that encompasses both the capsule containment and the specimen holder. This capsule design removes any thermal contact resistance that would be present when a two-part holder-housing interface is used; thus, lowering the overall temperatures of the capsule parts. Aside from having the holder and housing combined to a single part, this low temperature design is conceptually similar to the higher temperature design.

The specimens have relatively large variances in the coil diameters because of service use, as well as the initial sponsor-led cutting operation used to section the full spacer into individual specimens. In general, diametrically larger coils will exhibit larger heat fluxes due to a smaller secondary gas gap, resulting in large temperature variances during irradiation. The insulating buffer reduces the large temperature gradients because $\mathrm{ZrO}_{2}$ exhibits a much lower thermal conductivity than aluminum, thereby reducing heat transfer sensitivities caused by nonuniform secondary gas-gaps and contact between the specimen and the holder. For severely deformed specimens, two buffers of different wall thicknesses are used to provide a more consistent secondary gas gap over the axial length of the specimen. The $\mathrm{Al}$ insert is placed within the specimen to straighten the spring coils and to hold the SiC thermometry in place. Remaining spaces in the capsule are filled with quartz wool (between the specimen holder and the housing) to insulate the subassembly, preventing axial heat loss to the housing and minimizing movement. As described earlier, the housing features an inertia-welded transition from aluminum to stainless steel that mates with a 
stainless-steel endcap. This design feature increases the reliability of the housing-endcap weld in a hot cell environment.
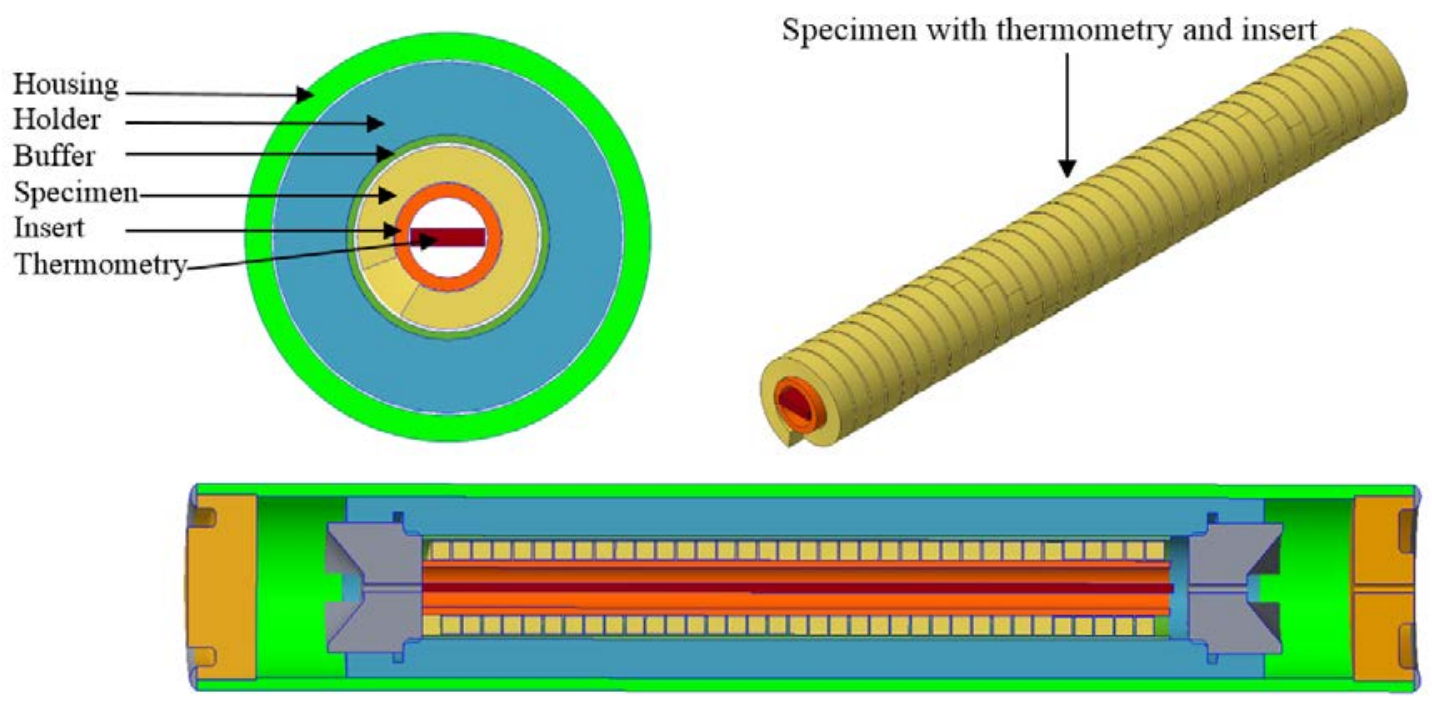

Figure 1. Section views showing irradiation capsule design concept and CAD representation of the specimen.

Table 1. Summary of the experiment assembly and part detail drawings

\begin{tabular}{ll}
\hline Drawing & Title \\
\hline X3E020977A680, Rev. 0 [5] & Target Capsule Al/SST Transition Housing/Bottom Cap Details \\
X3E020977A681, Rev. 0 [6] & Target Capsule Al/SST Transition Housing/End Cap Assembly \\
S17-37-CNL_RABBIT, Rev. 0 [7] & CNL Non-Optimized Spring Rabbit Capsule Assembly \\
S17-38-CNL_RABBIT, Rev. 0 [8] & CNL Non-Optimized Spring Rabbit Capsule Assembly Part Details \\
\hline
\end{tabular}

\subsection{SPRING PROFILING AND PREPARATION}

As stated above, pre-irradiated specimens were deformed due to service usage and the sectioning procedure. Because the thermal performance depends, in part, on the profile of the springs via the specimen-buffer gas gap, accurate inspection of the diametric variance along the length of the specimen was essential for accurate modeling and design. Initially, specimens were measured using gauges, but this method did not capture the profile with adequate precision. Therefore, a visual inspection system was fabricated in house and approved for hot cell use. This system uses a commercially available motorized stage and digital microscope.

\subsubsection{Specimen Imaging}

Imaging was performed using a Celestron Digital Microscope Pro with a universal serial bus (USB) output to a computer with Celestron Microcapture Pro software. Custom parts were machined to fasten the microscope to a motorized stage (Thorlabs NRT-150). The stage was controlled by a BSC201 motion controller connected to a computer running Thorlabs Kinesis (v 1.14.7.0 64 bit) control software. A custom specimen platform was designed, and 3D printed (FlashForge Creator Pro) with a semi-cylindrical channel to position the specimen on the stage so that the focal point of the microscope coincided with the same plane as the spring edge and the optical scale. Using this setup, images were taken of each spring section incrementally along the length of the specimen. Images of the platform and motorized stage can 
be seen in Figure 2. Since the specimens are not homogeneously circular, each specimen was rotated 90 degrees and profiled a second time. The schematic diagram of the imaging setup is illustrated in Figure 3.
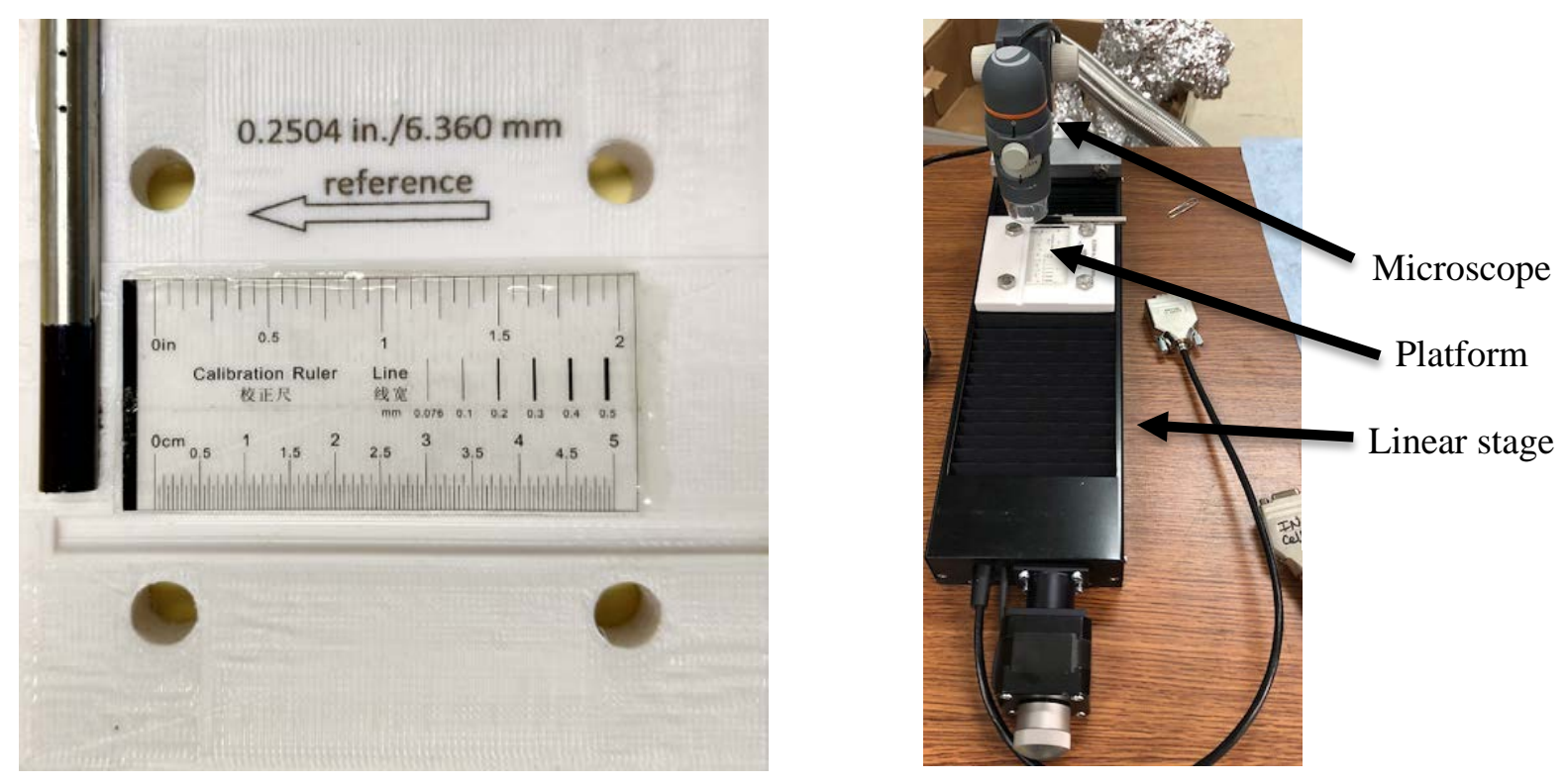

Figure 2. 3D printed platform (left) and assembled motorized stage (right).

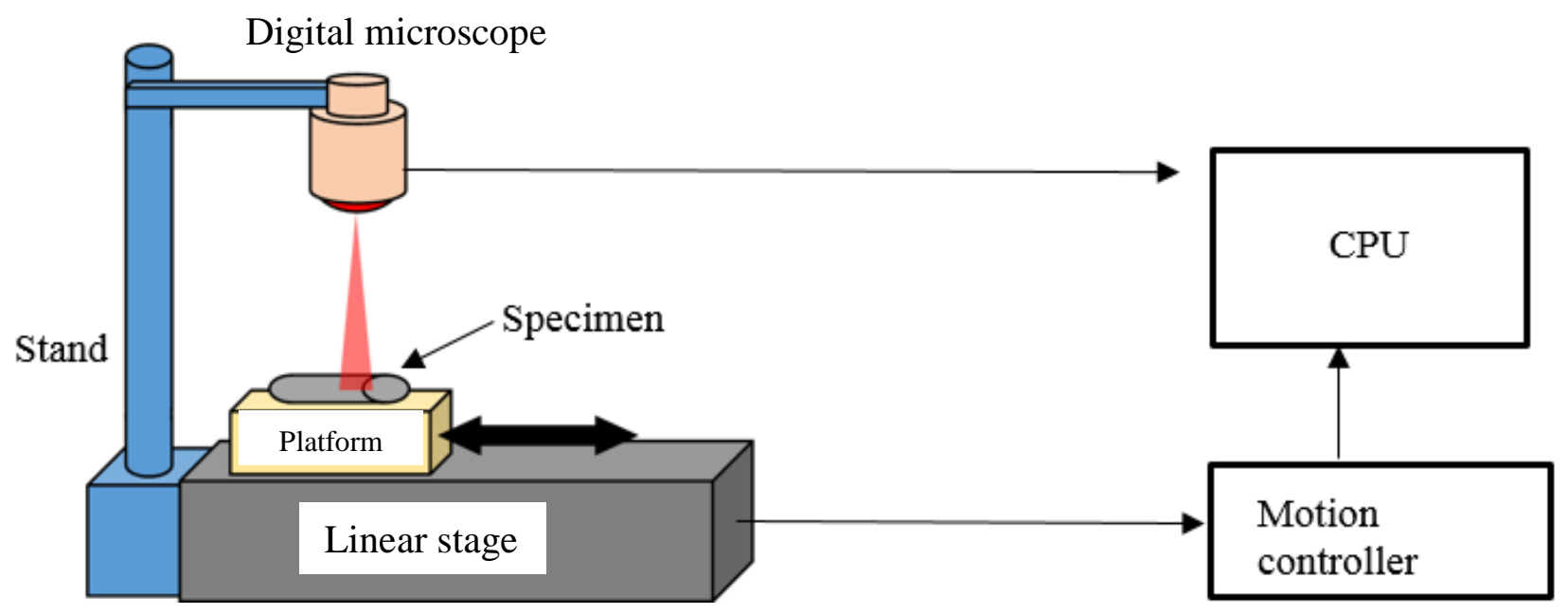

Figure 3. Schematic diagram of specimen profiling setup in the hot cell. 


\subsubsection{Image Analysis Methods}

Multiple images of each specimen were stitched using ImageJ and the Microscopy Image Stitching Tool (MIST), along with the phase-correlation image alignment method $[9,10]$. The specimen was measured in ImageJ by calibrating the pixels to the optical length scale positioned next to the specimen. For each specimen 30-35 diameter measurements were made (at both orientations). To accurately capture the profile of each specimen, it was necessary to characterize the effect of bowing and coil offset. With these features present, a series of individual coil diameter measurements did not provide the actual effective diameter and complementary buffer diameter. Given that the garter springs were wrapped around a CANDU reactor pressure tube during operation, the springs take on a permanent bowed shape that tends to smear the effective diameter of the spring (see Figure 4). The springs also become relaxed during their time in reactor due to the stretching and rolling of the spring as the pressure tube thermally expands radially and axially during operation. This imparts a non-trivial taper on the diameter that is most noticeable in the 6 o'clock position where the pressure tube resides in contact with the garter spring; this is known as the pinched region. This nonuniform taper can be seen in the measured coil diameters, which were merged in Figure 5. Note that the outlying data points are located at the ends of two data sets (\#2 and \#4) and correspond to data measured from partial coils resulting from cutting the garter spring.

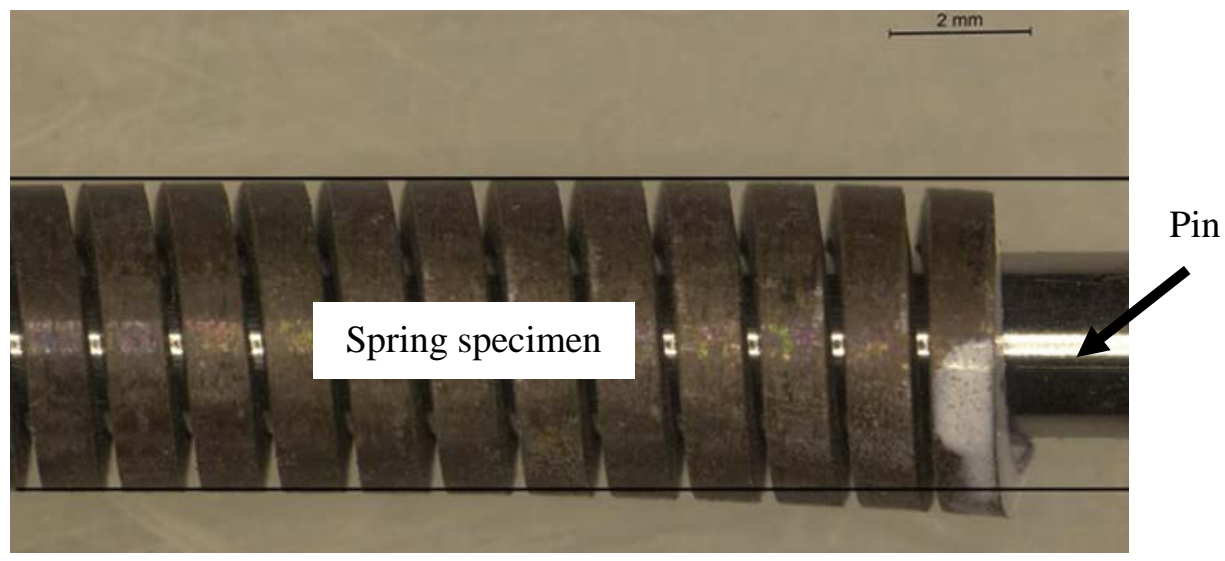

Figure 4. Garter spring specimen with emphasis on the bowing feature due to being wrapped around an operating pressure tube.

Investigation of the measured data and the size of the pins used to physically straighten the springs during profiling revealed that all specimens required some number of coils to be trimmed to ensure the best fit possible between each spring specimen and the buffer. During the initial cutting operation, the sponsor used plier-type side cutters to reduce the taper of the coil at the cut site. However, this approach tended to flare out the cut coil and amplify the effective diameter of the spring at the cut ends. Moreover, the steel pin diameters were sized to be $2.90 \mathrm{~mm}$ (0.114 in.) and were relatively loose fitting inside the spring specimen, which allowed the spring to bow slightly about the pin. The design team ascertained that a 2.97 $\mathrm{mm}(0.117 \mathrm{in}$.) diameter pin would sufficiently reduce this bowing and that only 1-2 coils were required to be trimmed from the cut ends of the spring. 


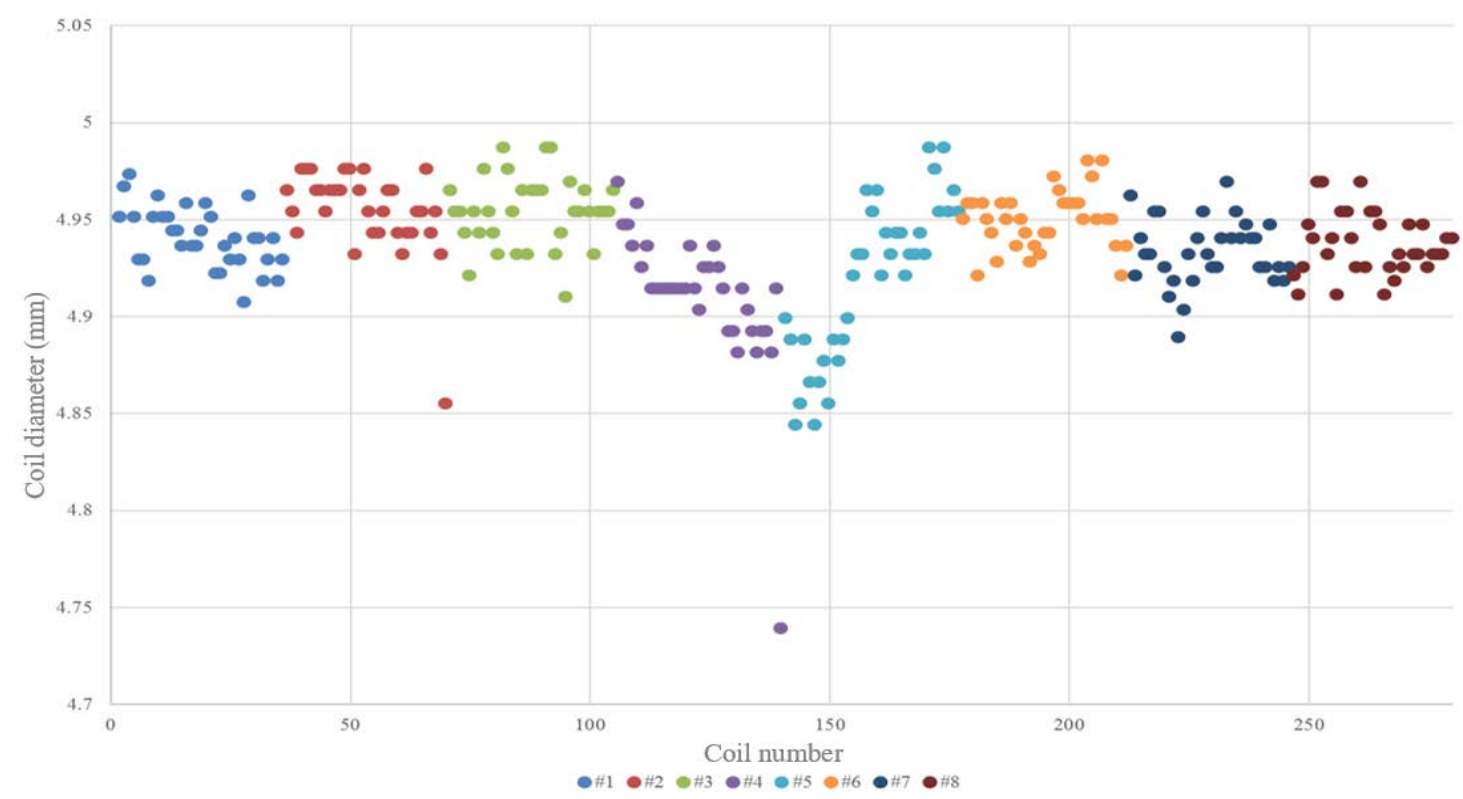

Figure 5. Measured coil data merged to show diametrical taper (pinched region corresponds to data sets 4 and 5; see APPENDIX A for raw data).

\subsubsection{Cutting and Gauge Validation}

Three flared coils on each spring end were removed with a customized IsoMet ${ }^{\mathrm{TM}}$ low speed saw to allow for better fit of the specimen within the buffer and to reduce temperature variances created by coils with non-uniform outer diameters (ODs) (see Figure 6). Further, a larger centering pin was placed through the center of the specimens to ensure that the spring specimens produce the most optimal effective diameter. Lastly, all specimens were tested in gauge blocks to verify that these corrective actions were successful and that the fit-up performance of all specimens was acceptable.

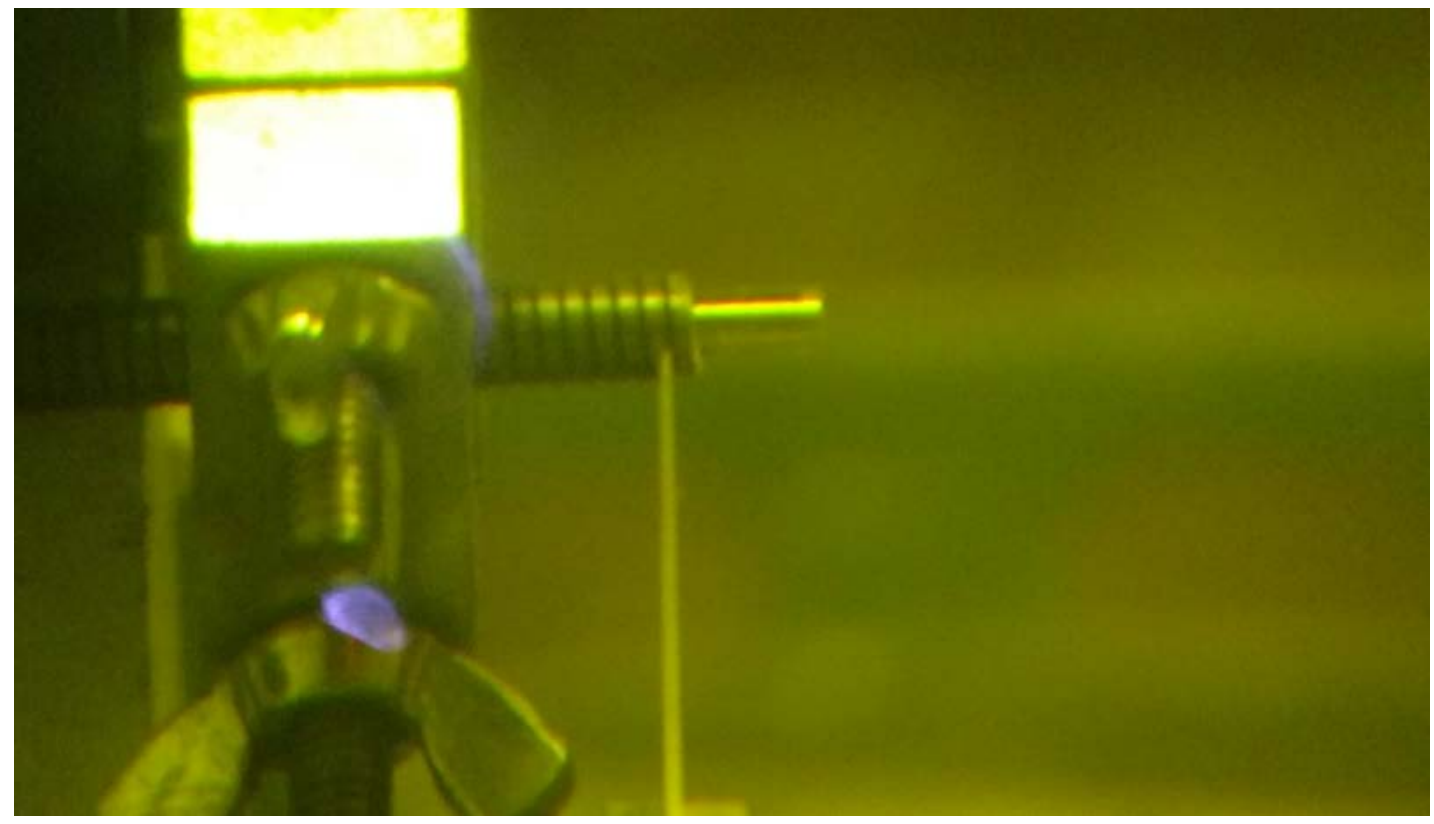

Figure 6. Low-speed saw cutting of a garter spring sample to remove a flared coil. 


\section{COMPUTATIONAL METHODS}

\subsection{THERMAL ANALYSIS}

Three-dimensional (3D) thermal analyses were performed using the ANSYS finite element software package to predict the thermal performance inside the experiment capsules. These analyses used materialdependent heat generation rates (heat per unit mass) as thermal loading conditions, which were calculated from previously performed neutronics analyses. Custom, user-defined macros have been incorporated into ANSYS to determine thermal contact conductance between components that are either in contact or separated by small gas-gaps that expand or contract due to thermal effects [11]. Parametric computeraided design (CAD) models are imported into ANSYS and meshed. The measured profiles of the specimens were designed into the CAD model to reflect the nonuniform specimen profiles. Gas gap heat transfer is assumed to include conduction only, as there is very little space available for natural convection to occur. Gaps are typically on the order of microns to a few millimeters, and the total internal length of the capsule is less than $60 \mathrm{~mm}$.

The ORNL Nuclear Experiments and Irradiation Testing (NEIT) Group maintains a database of design and analysis calculations (DACs) that include temperature-dependent (and in some cases radiation dosedependent) thermophysical material properties used in thermal analyses. Properties are primarily obtained from CINDAS [12], MatWeb [13], and various literature sources. Material properties for this calculation are included in the DACs shown in Table 2 are available upon request.

Inconel X-750 has been observed to swell due to irradiation. Additionally, it is suggested that the amount of swelling has temperature dependence. The amount of swelling with respect to dose was measured using density measurements provided by the sponsor. Reaction rate theory calculations were performed to predict the expected swelling in HFIR in different temperature regimes. The calculated swelling with respect to temperature in a commercial CANDU reactor and HFIR are shown in Figure 7 [14]. This concurred with the density measurements completed by the sponsor.

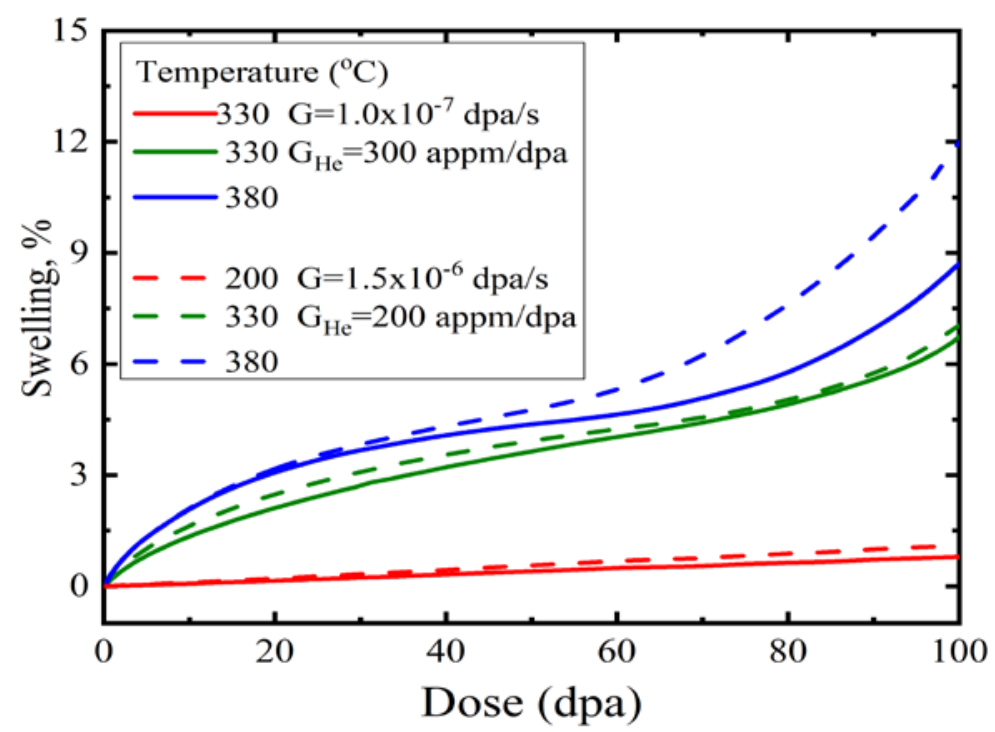

Figure 7. Rate theory calculations of Inconel X-750 volumetric swelling at varying dose and temperatures [15]. 
Table 2. Experiment materials and material property references

\begin{tabular}{lll}
\hline Part & Material & Reference \\
\hline Housing, end cap & Aluminum & DAC-10-03-PROP_AL6061 [11] \\
Holder & Aluminum & DAC-10-03-PROP_AL6061 [11] \\
Buffer & Zirconium Dioxide & DAC-11-08-PROP_ZRO2 [15] \\
Specimen & Inconel & DAC-13-01-PROP_INCONEL [16] \\
Insert & Aluminum & DAC-10-03-PROP_AL6061 [11] \\
Thermometry & Silicon carbide & DAC-10-06-PROP_SIC(IRR) [17] \\
Fill gas & Helium & DAC-10-02-PROP_HELIUM [18] \\
\hline
\end{tabular}

The convection boundary condition, along with the reactor bulk coolant temperature, was applied to the outer surface of the capsule housing. The convective heat transfer coefficient is particular to the TRRH irradiation facility, which was the focus facility of this design. The derivation of this value can be found in DAC-11-01-RAB03 [19].

Heat generation rates vary in each HFIR position and as a function of axial position from the midplane of the reactor core. Peak heat generation rates (at the core midplane), parameters for determining the axial profile, and convection parameters are summarized in Table 3. Neutronic calculations were not carried out for this particular design but calculations were performed previously [20] [21] for other experiments with similar materials and capsule configurations, which yielded heat generation rates that are appropriate for this work.

Table 3. Thermal boundary conditions

\begin{tabular}{lc}
\hline Parameter & Value in TRRH \\
\hline Heat transfer coefficient & $47.1 \mathrm{~kW} \mathrm{~m}^{-2} \mathrm{~K}^{-1}$ \\
Bulk coolant temperature & $52^{\circ} \mathrm{C}$ \\
Peak heat generation rate for aluminum & $32.5 \mathrm{~W} / \mathrm{g}$ \\
Peak heat generation rate for titanium & $35.2 \mathrm{~W} / \mathrm{g}$ \\
Peak heat generation rate for Inconel & $39.3 \mathrm{~W} / \mathrm{g}$ \\
Peak heat generation rate for $\mathrm{ZrO}_{2}$ & $52.0 \mathrm{~W} / \mathrm{g}$ \\
Peak heat generation rate for $\mathrm{SiC}$ & $32.9 \mathrm{~W} / \mathrm{g}$ \\
Correlating parameter $(\sigma)$ & $30.07 \mathrm{~cm}$ \\
\hline
\end{tabular}

The local heat generation rate is estimated with the following profile:

$$
\mathrm{q}(\text { material, } \mathrm{z})=\mathrm{q}_{\text {peak }}(\text { material }) \cdot \exp \left[-\left(\frac{\mathrm{z}}{\sigma}\right)^{2}\right]
$$

where:

$\mathrm{q}=$ local heat generation rate as a function of the material and axial location,

$\mathrm{q}_{\mathrm{peak}}=$ heat generation rate at the HFIR midplane as a function of material,

$\mathrm{z}=$ axial location in the HFIR, where the midplane is at $\mathrm{z}=0$, and

$\sigma \quad=$ correlating parameter.

Figure 8 shows one example of a fully meshed 3D finite element model. Most of the components were meshed using $0.4-0.5 \mathrm{~mm}$ sized hexagonal elements. The thins buffer and thermometry housing were meshed with 0.1-0.2 mm sized elements. The spring was not meshed with hexagonal elements due to its complexity. The "distorted" shown in Figure 9 elements are only a result of the section view. 


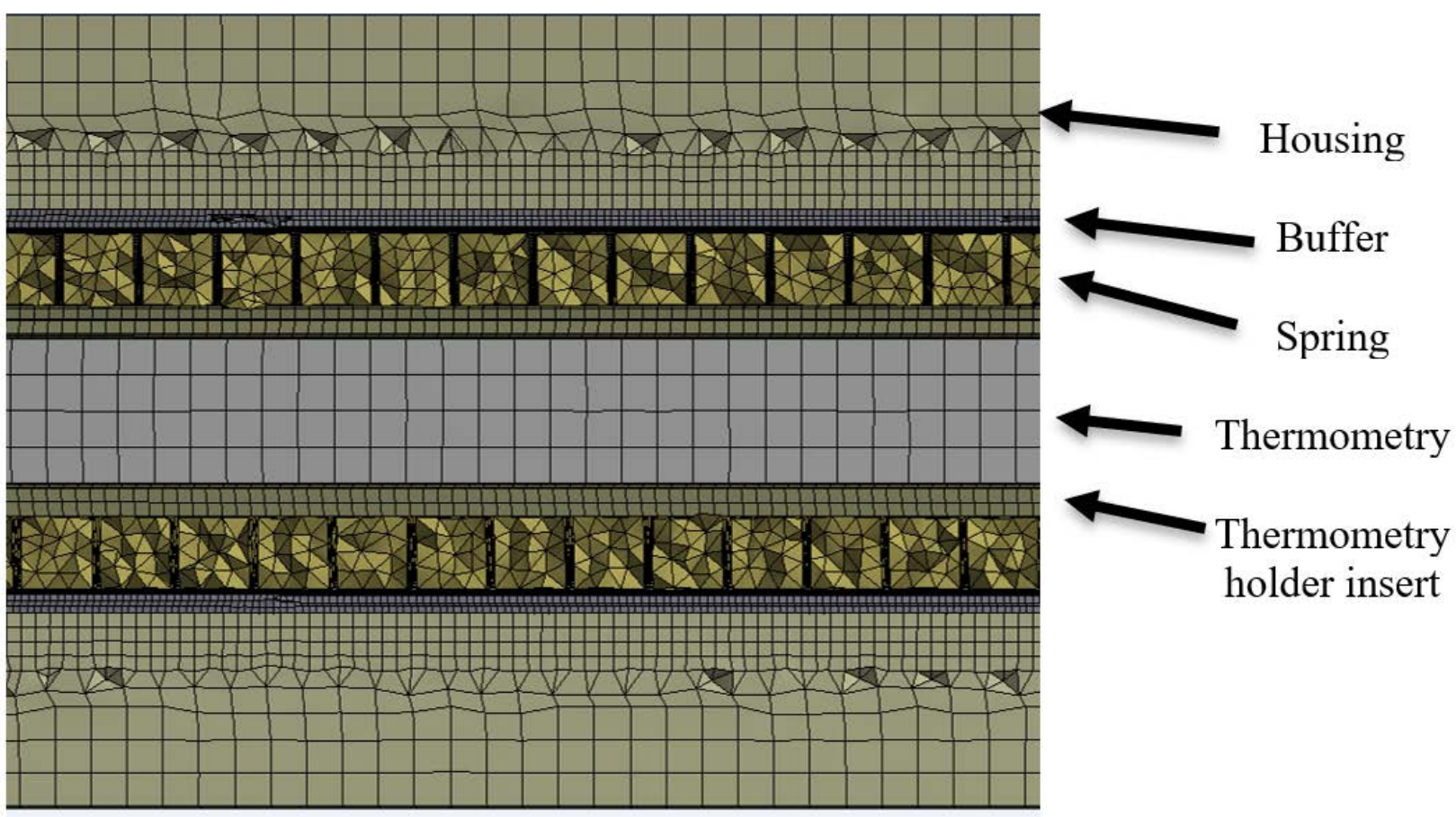

Figure 8. Partial section view of meshed 3D thermal finite element model

\section{RESULTS AND DISCUSSION}

\subsection{SPECIMEN PROFILES}

As mentioned in Section 2.2, precise dimensional inspection was required to allow for accurate predictions of the specimen's temperature gradients, since the gap between the specimen and the buffer is a secondary mode of temperature control. The average coil diameter was $4.94 \mathrm{~mm}$ with a standard deviation of $0.03 \mathrm{~mm}$. The difference between the minimum and maximum coil OD was determined to be $0.25 \mathrm{~mm}$. The tapered profile described earlier (see Figure 5) trends from a large OD of roughly $4.98 \mathrm{~mm}$ to a small OD of $4.84 \mathrm{~mm}$, or vice versa. To account for a gap disparity that would exist with a uniform inner diameter (ID) buffer, a split design was chosen to better maintain the gap size along the specimen length and reduce thermal gradients. All the specimens were observed to have large end coils because of the mechanically deforming cutting procedure used to section the full-length spacer. This factor, along with the curvature of the specimens, would prevent easy placement of the specimen into an appropriately sized buffer. The assembly will be performed using master-slave manipulators (MSMs) with limited dexterity, and optimizing the buffer is a key design constraint. As stated in Section 2, the maximum effective diameter was determined for each specimen through image analysis of the specimen's curvature. This was verified by dropping the specimens through gauge blocks. All the specimens were able to pass through a hole of $5.1 \mathrm{~mm}$ in diameter, and the narrow ends of specimens 4 and 5 were also tested with a $5.06 \mathrm{~mm}$ diameter hole. These data were used to size the buffer's IDs for the subsequent thermal models.

\subsection{THERMAL ANALYSIS}

\subsubsection{Test Matrix and Evaluation Cases}

Thermal analyses were performed for each specimen capsule to be irradiated. These analyses provide the part dimensions required to meet the desired temperature goals for each specimen (i.e., sizes of the buffer 
and holder). Due to the unique profile of each specimen, the design dimensions were analyzed for each individual specimen. Two specimen temperature regimes were desired, $330^{\circ}$ and $200^{\circ} \mathrm{C}$ (or as low as achievable). The specimens were assumed to be straight with no bowing, and the IDs and ODs were assumed to be perfectly circular. The average of the two profiles ( 0 and $90^{\circ}$ rotation) was used, as the difference between the major and minor axes was deemed to have an insignificant effect on the thermal performance. The averaged diametric measurements for each specimen were transferred to the CAD model by setting the diameter at equidistant points along the specimen model. Coils falling between the points were modeled by linear interpolation of adjacent points. Buffers were modeled as a plain hollow cylinder, except when dual thicknesses were required, as for specimens 4 and 5 . In those cases, the buffer was made of two cylinders (of equal length) and the ID at the narrower specimen end was slightly decreased. The volumetric swelling was computed using the rate theory as explained in Section 3.1. Assuming isotropic swelling, the total volumetric swelling by the end of irradiation (EOI) was computed using the following:

$$
\frac{\Delta V}{V}=D P A_{\text {PerCycle }} * N_{\text {cycles }} * \varepsilon_{V}(T, D P A)
$$

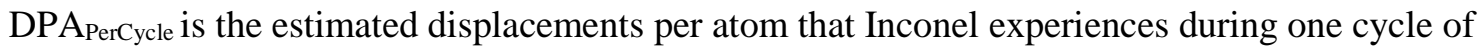
irradiation in HFIR ( 25 days). Previous work has shown that Inconel, like materials such as stainless steel, receive a neutron damage rate of $2 \mathrm{DPA}$ /cycle. $\mathrm{N}_{\text {cycles }}$ is the number of cycles the specimens will be irradiated, and $\varepsilon_{V}(T, D P A)$ is the temperature-dose-dependent volumetric strain. A volumetric strain $\left(\varepsilon_{V}\right)$ of $3.2 \%$ per $100 \mathrm{DPA}$ was used for the $330^{\circ} \mathrm{C}$ irradiations, while the swelling at the lower temperature case would be $1 \%$ per 100 DPA and should have negligible impact on thermal performance. Therefore, swelling was neglected for the $230^{\circ} \mathrm{C}$ simulations. The swelling was introduced to the CAD model through a linear scaling factor. The scaling factor, equivalent to linear swelling $\left(\varepsilon_{l}\right)$, was calculated as $\varepsilon_{1}=$ $\varepsilon_{\mathrm{v}} / 3$, which is generally true for small strains. Additionally, the stainless-steel section of the housing and the end caps were neglected, as they would have negligible impact on the overall performance of the specimens since they would be insulated by quartz wool. The temperature predictions presented in this report are characteristic of irradiations at the TRRH-4 position. However, irradiations will occur at TRRH-3 through TRRH-5 positions. Therefore, the $230^{\circ} \mathrm{C}$ designs are planned to be placed at positions 3 and 5 , subject to $\sim 5 \%$ reduction in the heat generation rates. The actual temperatures should be slightly lower than those listed. The $330^{\circ} \mathrm{C}$ cases are planned to be placed at the TRRH-4 positions.

Table 4 summarizes the irradiation test matrix, specimen number, desired temperature, dose, corresponding volumetric swelling, holder sizes, and buffer sizes.

Table 4. Irradiation test matrix, design temperature, buffer dimensions, and holder dimensions

\begin{tabular}{cccccccc}
\hline Capsule & Position & $\begin{array}{c}\text { Number } \\
\text { of cycles }\end{array}$ & $\begin{array}{c}\text { Design } \\
\text { temperature } \\
\left({ }^{\circ} \mathbf{C}\right)\end{array}$ & $\begin{array}{c}\text { Volumetric } \\
\text { swelling } \\
\mathbf{\Delta V / V}(\mathbf{\%})\end{array}$ & $\begin{array}{c}\text { Buffer ID } \\
\mathbf{( m m})\end{array}$ & $\begin{array}{c}\text { Holder ID/ } \\
\text { buffer OD } \\
(\mathbf{m m})\end{array}$ & $\begin{array}{c}\text { Holder } \\
\text { OD (mm) }\end{array}$ \\
\hline 1 & TRRH 4 & 10 & 330 & 0.64 & 5.10 & 6.00 & 9.42 \\
2 & TRRH 4 & 10 & 230 & $\sim 0$ & 5.10 & 5.60 & $9.52^{* *}$ \\
3 & TRRH 4 & 20 & 230 & $\sim 0$ & 5.10 & 5.60 & $9.52^{* *}$ \\
4 & TRRH 4 & 15 & 230 & $\sim 0$ & $5.10 / 5.06^{*}$ & 5.60 & $9.52^{* *}$ \\
5 & TRRH 4 & 25 & 230 & $\sim 0$ & $5.10 / 5.06^{*}$ & 5.60 & $9.52^{* *}$ \\
6 & TRRH 4 & 20 & 330 & 1.28 & 5.10 & 6.00 & 9.42 \\
7 & TRRH 4 & 15 & 330 & 0.96 & 5.10 & 6.00 & 9.42 \\
8 & TRRH 4 & 25 & 330 & 1.60 & 5.10 & 6.00 & 9.41 \\
\hline
\end{tabular}

*There are two IDs for the split buffer designs.

**The cold capsule designs feature a thick-walled housing. The holder and the housing are one continuous part. 


\subsubsection{Predicted Temperatures}

Figure 9 shows an example of temperature contours for the rabbit assembly and specimens for a $330^{\circ} \mathrm{C}$ capsule design at a TRRH-4 position at the core midplane. It was observed that several coils display hot/cold spots, due to the nonuniform outer diameters of the springs. There also seemed to be a temperature gradient moving from one end of the specimen to the other (top to bottom in Figure 9). This was likely caused by the tapered specimen profile. The thermal performance of each specimen is unique and depends on its profile. The designs were optimized to minimize temperature spans while still reaching the desired average temperature goal.

Table 5 summarizes calculated average, minimum, and maximum temperatures for the specimens in each capsule. Table 6 summarizes calculated average, minimum, and maximum temperatures for the thermometry, which will be compared to temperatures determined post-irradiation using dilatometry. Specimen minimums and maximums were calculated by removing the top and bottom $2.5 \%$ elementvolume-averaged temperatures (the calculated averages did not remove the outliers). This was done to reduce the contribution of outliers from skewing the reported temperatures. More details are provided in the full ANSYS output files in APPENDIX B.

Average specimen temperatures for the $330^{\circ} \mathrm{C}$ cases ranged from $334-336^{\circ} \mathrm{C}$, which fell within the desired range at the beginning of irradiation (BOI). Irradiation-induced swelling results in a small reduction in specimen temperatures due to reduction of the secondary gas gap. The average end of irradiation (EOI) temperatures for the $330^{\circ} \mathrm{C}$ designs range from $323-327^{\circ} \mathrm{C}$. During irradiation, the temperatures will fall somewhere between the BOI and EOI temperatures. For the colder $230^{\circ} \mathrm{C}$ or lower capsule design, the average temperatures range from $228-235^{\circ} \mathrm{C}$. Although it was assumed to be negligible, the irradiation-induced swelling is non-zero for these specimens and may have some minor contribution for the $230^{\circ} \mathrm{C}$ capsule designs, especially for longer irradiations. However, it would only cause a temperature decrease by reducing the secondary gas gap. Further, these designs were modeled at the TRRH-4 positions, and placement at the 3 or 5 positions would also cause slight reduction in temperature. These results are more representative of the maximum temperature the specimens should experience during irradiation.

Table 5. Predicted specimen temperatures for each capsule at BOI and EOI

\begin{tabular}{ccccccccc}
\hline \multirow{2}{*}{ Capsule/Specimen\# $\begin{array}{c}\text { Design } \\
\text { temperature } \\
\end{array}$} & \multirow{2}{*}{$\begin{array}{c}\text { Number of } \\
\text { cycles }\end{array}$} & & $\begin{array}{c}\text { Avg. } \\
\left({ }^{\circ} \mathbf{C}\right)\end{array}$ & $\begin{array}{c}\text { Min.* } \\
\left({ }^{\circ} \mathbf{C}\right)\end{array}$ & $\begin{array}{c}\text { Max.* } \\
\left({ }^{\circ} \mathbf{C}\right)\end{array}$ & $\begin{array}{c}\text { Avg. } \\
\left({ }^{\circ} \mathbf{C}\right)\end{array}$ & $\begin{array}{c}\text { Min.* } \\
\left({ }^{\circ} \mathbf{C}\right)\end{array}$ & $\begin{array}{c}\text { Max.** } \\
\left({ }^{\circ} \mathbf{C}\right)\end{array}$ \\
\hline 1 & 330 & 10 & 334 & 321 & 346 & 327 & 314 & 339 \\
2 & 230 & 10 & 234 & 224 & 246 & n/a & n/a & n/a \\
3 & 230 & 20 & 228 & 218 & 237 & n/a & n/a & n/a \\
4 & 230 & 15 & 234 & 222 & 246 & n/a & n/a & n/a \\
5 & 230 & 25 & 235 & 214 & 257 & n/a & n/a & n/a \\
6 & 330 & 20 & 334 & 319 & 345 & 324 & 309 & 335 \\
7 & 330 & 15 & 334 & 324 & 343 & 326 & 316 & 336 \\
8 & 330 & 25 & 336 & 327 & 343 & 323 & 314 & 331 \\
\hline
\end{tabular}

*Minimum and maximum values determined from 2.5 and 97.5 percentiles of temperature nodes. 


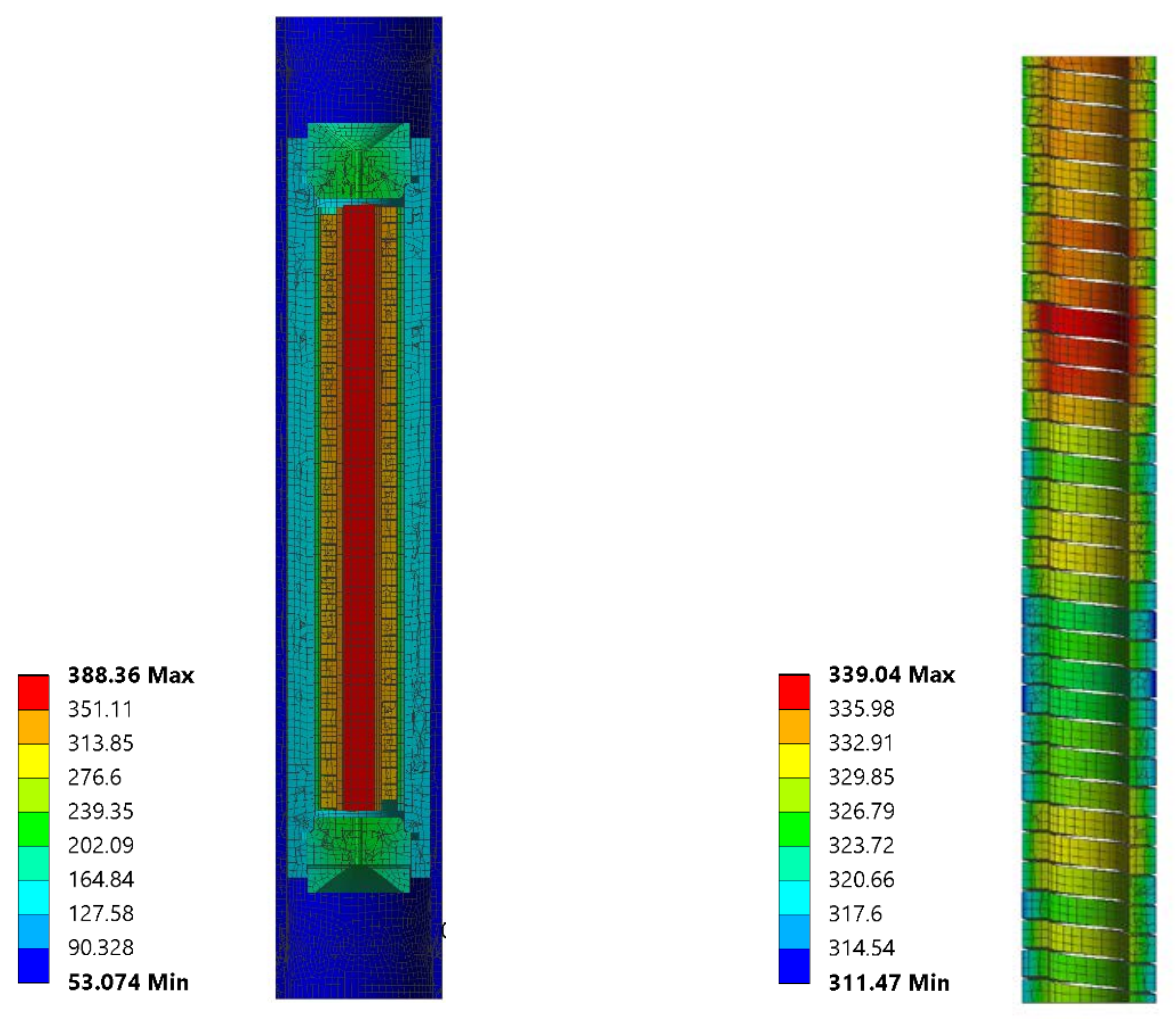

Figure 9. Temperature contours $\left({ }^{\circ} \mathrm{C}\right)$ for a rabbit assembly (left) and specimen (right).

Table 6. Predicted passive temperature monitor (TM) temperatures for each rabbit at the BOI and EOI

\begin{tabular}{ccccccccc}
\hline \multirow{2}{*}{ Capsule } & \multirow{2}{*}{$\begin{array}{c}\text { Design } \\
\text { temperature } \\
\left({ }^{\circ} \mathbf{C}\right)\end{array}$} & $\begin{array}{c}\text { Number of } \\
\text { Cycles }\end{array}$ & $\begin{array}{c}\text { Avg. } \\
\left({ }^{\circ} \mathbf{C}\right)\end{array}$ & $\begin{array}{c}\text { Min. } \\
\left({ }^{\circ} \mathbf{C}\right)\end{array}$ & $\begin{array}{c}\text { Max. } \\
\left({ }^{\circ} \mathbf{C}\right)\end{array}$ & $\begin{array}{c}\text { Avg. } \\
\left({ }^{\circ} \mathbf{C}\right)\end{array}$ & $\begin{array}{c}\text { Min. } \\
\left({ }^{\circ} \mathbf{C}\right)\end{array}$ & $\begin{array}{c}\text { Max. } \\
\left({ }^{\circ} \mathbf{C}\right)\end{array}$ \\
\hline 1 & 330 & 10 & 383 & 368 & 397 & 377 & 362 & 391 \\
2 & 230 & 10 & 288 & 278 & 304 & n/a & n/a & n/a \\
3 & 230 & 20 & 282 & 275 & 288 & n/a & n/a & n/a \\
4 & 230 & 15 & 284 & 273 & 301 & n/a & n/a & n/a \\
5 & 230 & 25 & 285 & 268 & 307 & n/a & n/a & n/a \\
6 & 330 & 20 & 383 & 368 & 396 & 374 & 360 & 388 \\
7 & 330 & 15 & 383 & 373 & 394 & 376 & 366 & 388 \\
8 & 330 & 25 & 385 & 376 & 497 & 375 & 365 & 387 \\
\hline
\end{tabular}

Note: The min and max are taken as absolute, without the rejection of outliers. 


\section{SUMMARY AND CONCLUSIONS}

This work summarizes the specimen inspections, capsule design, and thermal analyses that were performed to support the qualification of a new irradiation vehicle for B8J18 Inconel X-750 ex-service garter spring spacer sections in HFIR. Upon completion of their irradiation schedules, the specimens will undergo PIE, including crush testing and transmission electron microscopy, to enhance understanding of high neutron dose mechanical performance of this material. A single garter spring was sectioned to produce eight unique samples for irradiation testing. Several unique capsule designs were produced to allow these specimens to achieve specific target irradiation temperatures in accordance with sponsor requirements. The design process included performing dimensional inspection using high resolution imaging techniques, modifying the specimens through cutting and elastic straightening to ensure optimal specimen geometries, and employing unique, versatile $\mathrm{ZrO}_{2}$ buffers within a novel capsule designs to provide adequate design performance and constructability in a hot cell environment. 


\section{REFERENCES}

[1] I. F. Ibrahim, "Examination of gerter springs from CANDU® reactors.," Atomic Energy of Canada Limited, AECL-8767, Deep River, Ontario, CA, 1985.

[2] Oak Ridge National Laboratory, "High Flux Isotope Reactor Technical Parameters," [Online]. Available: http://neutrons.ornl.gov/hfir/parameters. [Accessed 27 July 2016].

[3] A. Campbell, W. Porter, Y. Katoh and L. Snead, "Method for analyzing passive silicon carbide thermometry with a continuous dilatometer to determine irradiation temperature," Nuclear Instruments and Methods in Physics Research B, vol. 370, pp. 49-58, 2016.

[4] R. H. Howard, R. C. Gallagher and K. G. Field, "Mechanical performance of neutron-irradiated dissimilar transition joints of aluminum alloy 6061-T6 and 304L stainless steel.," Journal of Nuclear Materials, https://doi.org/10.1016/j.jnucmat.2018.05.070, 2018.

[5] R. Howard, X3E020977A680 R0, Target Capsule AL/SST Transition Housing/Bottom Cap Details, NEIT, 2018.

[6] R. Howard, X3E020977A681 R0, Target Capsule AL/SST TransitionHousing/End Cap Assembly, NEIT, 2018.

[7] R. Howard, S17-37-CNL_RABBIT R0, CNL Non_Optimized Spring Rabbit Capsule Assembly, NEIT, 2018.

[8] R. Howard, S17-38-CNL_RABBIT R0, CNL Non-Optimized Spring Rabbit Capsule Assembly Part Details, NEIT, 2018.

[9] J. Schindelin, C. T. Rueden, M. C. Hiner and K. W. Eliceiri, "The ImageJ ecosystem: An open platform for biomedical image analysis," Molecular Reproduction and Development , vol. 82, no. 78, pp. 518-29, 2015.

[10] J. Chalfoun, "MIST: Accurate and Scalable Microscopy Image Stitching Tool with Stage Modeling and Error Minimization," Scientific Reports, vol. 7, 2017.

[11] J. McDuffee, "Thermophysical Properties for AL6061," Oak Ridge National Laboratory, Thermal Hydraulics and Irradiation Engineering Group, Oak Ridge, TN, 2013.

[12] CINDAS, LLC, "CINDAS, LLC: Global Benchmark for Critically Evaluated Materials Properties Data," [Online]. Available: http://cindasdata.com. [Accessed 10 February 2017].

[13] MatWeb, LLC, "MatWeb: Material Property Data," [Online]. Available: http://matweb.com/. [Accessed 10 February 2017].

[14] S. I. Golubov and K. J. Leonard, Swelling calculations of Inconel in a commercial reactor versus the HFIR (Email Correspondence), 2018.

[15] R. Howard, "DAC-11-08-PROP_ZRO2 Rev.1: Thermophysical Properties of ZrO2," Oak Ridge National Laboratory, Oak Ridge, TN.

[16] R. Howard, "Thermophysical Properties for Inconel X-750," Oak Ridge National Laboratory, Oak Ridge Tennessee, 2013.

[17] J. McDuffee, "Thermophysical Properties for Irradiated Silicon Carbide," Oak Ridge National Laboratory, Oak Ridge, TN, 2016.

[18] J. McDuffee, "Thermophysical Properties for Helium," Oak Ridge National Laboratory, Oak Ridge, TN, 2010.

[19] J. McDuffee, "Heat Transfer Coefficients and Bulk Temperatures for HFIR Rabbit Facilities," Oak Ridge National Laboratory, Thermal Hydraulics and Irradiation Engineering Group, Oak Ridge, TN, 2011. 
[20] C. Daily, "Heat Generation Rates for Various Titanium and Silicon Compounds in the Flux Trap of HFIR," Oak Ridge National Laboratory, Oak Ridge, TN, 2013.

[21] J. McDuffee, "Heat Generation Rates for Various Rabbit Materials in the Flux Trap of HFIR," Oak Ridge National Laboratory, Thermal Hydraulics and Irradiation Engineering Group, Oak Ridge, TN, 2011. 
APPENDIX A. DIMENSIONAL INSPECTION 


\section{APPENDIX A. DIMENSIONAL INSPECTION}

Table A-1. Diametrical Profile Measurements (mm)

\begin{tabular}{|c|c|c|c|c|c|c|c|c|c|c|c|c|c|c|c|}
\hline \multicolumn{2}{|c|}{ Specimen \#1 } & \multicolumn{2}{|c|}{ Specimen \#2 } & \multicolumn{2}{|c|}{ Specimen \#3 } & \multicolumn{2}{|c|}{ Specimen \#4 } & \multicolumn{2}{|c|}{ Specimen \#5 } & \multicolumn{2}{|c|}{ Specimen \#6 } & \multicolumn{2}{|c|}{ Specimen \#7 } & \multicolumn{2}{|c|}{ Specimen \#8 } \\
\hline $0^{\circ}$ & $90^{\circ}$ & $0^{\circ}$ & $90^{\circ}$ & $0^{\circ}$ & $90^{\circ}$ & $0^{\circ}$ & $90^{\circ}$ & $0^{\circ}$ & $90^{\circ}$ & $0^{\circ}$ & $90^{\circ}$ & $0^{\circ}$ & $90^{\circ}$ & $0^{\circ}$ & $90^{\circ}$ \\
\hline 4.931 & 4.917 & 4.857 & 4.916 & 4.967 & 4.989 & 4.741 & 4.875 & 4.901 & 4.850 & 4.952 & 4.894 & 4.964 & 4.934 & 4.942 & 4.950 \\
\hline 4.920 & 4.939 & 4.934 & 4.927 & 4.956 & 4.978 & 4.916 & 4.875 & 4.890 & 4.857 & 4.960 & 4.923 & 4.923 & 4.912 & 4.942 & 4.945 \\
\hline 4.942 & 4.906 & 4.956 & 4.949 & 4.956 & 4.978 & 4.883 & 4.886 & 4.846 & 4.872 & 4.960 & 4.908 & 4.942 & 4.934 & 4.934 & 4.950 \\
\hline 4.931 & 4.906 & 4.945 & 4.927 & 4.956 & 4.956 & 4.894 & 4.875 & 4.857 & 4.886 & 4.923 & 4.894 & 4.934 & 4.927 & 4.934 & 4.934 \\
\hline 4.920 & 4.906 & 4.978 & 4.905 & 4.934 & 4.967 & 4.894 & 4.907 & 4.890 & 4.879 & 4.960 & & 4.934 & 4.912 & 4.934 & \\
\hline 4.942 & 4.891 & 4.956 & 4.927 & 4.956 & 4.967 & 4.883 & 4.907 & 4.868 & 4.864 & 4.952 & 4.916 & 4.956 & 4.927 & 4.927 & 4.956 \\
\hline 4.942 & 4.965 & 4.956 & 4.938 & 4.967 & 4.978 & 4.894 & 4.929 & 4.846 & 4.864 & 4.945 & 4.908 & 4.956 & 4.941 & 4.949 & 4.961 \\
\hline 4.964 & 4.943 & 4.945 & 4.927 & 4.956 & 4.978 & 4.905 & 4.929 & 4.868 & 4.901 & 4.930 & 4.894 & 4.927 & 4.941 & 4.934 & 4.923 \\
\hline 4.909 & 4.891 & 4.945 & 4.938 & 4.956 & 4.967 & 4.916 & 4.907 & 4.879 & 4.872 & 4.960 & 4.908 & 4.912 & 4.963 & & 4.972 \\
\hline 4.931 & 4.928 & 4.934 & 4.916 & 4.971 & 4.967 & 4.883 & 4.896 & 4.857 & 4.872 & 4.952 & 4.901 & 4.920 & 4.941 & 4.949 & 4.972 \\
\hline 4.942 & 4.906 & 4.945 & 4.927 & 4.912 & 4.967 & 4.894 & 4.886 & 4.890 & 4.879 & 4.960 & 4.908 & 4.891 & 4.949 & 4.927 & 4.950 \\
\hline 4.931 & 4.972 & 4.967 & 4.949 & 4.945 & 4.967 & 4.894 & 4.940 & 4.879 & 4.886 & 4.938 & 4.90 & 4.905 & 4.912 & 4.934 & 4.961 \\
\hline 4.938 & 4.921 & 4.967 & 4.938 & 4.934 & 4.978 & 4.916 & 4.929 & 4.890 & 4.886 & 4.952 & 4.930 & 4.934 & 4.949 & 4.920 & 4.967 \\
\hline 4.924 & 4.943 & 4.956 & 4.949 & 4.989 & 4.978 & 4.927 & 4.940 & 4.901 & 4.894 & 4.945 & 4.9 & 4.920 & 4.956 & 4.92 & 4.950 \\
\hline 4.924 & 4.913 & 4.945 & 4.960 & 4.989 & 4.967 & 4.938 & 4.907 & 4.923 & 4.908 & 4.930 & 4.95 & 4.942 & 4.963 & 4.913 & 4.978 \\
\hline 4.953 & 4.913 & 4.945 & 4.938 & 4.967 & 4.956 & 4.927 & 4.918 & 4.934 & 4.930 & 4.938 & 4.9 & 4.956 & .963 & 4.949 & 4.961 \\
\hline 4.960 & 4.950 & 4.956 & 4.971 & 4.967 & 4.978 & 4.927 & 4.929 & 4.934 & 4.923 & 4.934 & 4.945 & 4.934 & 4.956 & 4.956 & 4.967 \\
\hline 4.946 & 4.943 & 4.978 & 4.938 & 4.967 & 4.967 & 4.905 & 4.9 & 4.967 & 4.923 & 4.945 & 4.9 & 4.927 & 4.949 & 4.956 & 4.967 \\
\hline 4.938 & 4.928 & 4.967 & 4.960 & 4.934 & 4.945 & 4.916 & 4.929 & 4.956 & 4.915 & 4.92 & 4.9 & 4.927 & 4.963 & 4.927 & 4.967 \\
\hline 4.938 & 4.950 & 4.934 & 4.949 & 4.967 & 4.945 & 4.938 & 4.929 & 4.967 & 4.930 & 4.974 & 4.901 & 4.942 & 4.963 & 4.971 & 4.961 \\
\hline 4.960 & 4.957 & 4.978 & 4.927 & 4.934 & 4.945 & 4.916 & 4.907 & 4.923 & 4.930 & 4.967 & 4.9 & 4.971 & 4.963 & 4.927 & 4.956 \\
\hline 4.938 & 4.950 & 4.978 & 4.949 & 4.956 & 4.934 & 4.916 & 4.951 & 4.945 & 4.952 & 4.960 & 4.9 & 4.942 & 4.978 & 4.942 & 4.967 \\
\hline 4.946 & 4.935 & 4.967 & 4.949 & 4.978 & 4.978 & 4.916 & 4.940 & 4.934 & 4.967 & 4.960 & 4.938 & 4.956 & 4.971 & 4.956 & 4.956 \\
\hline 4.946 & 4.957 & 4.967 & 4.938 & 4.989 & 4.934 & 4.916 & 4.929 & 4.945 & 4.959 & 4.960 & 4.93 & 4.942 & 4.949 & 4.956 & 4.961 \\
\hline 4.953 & 4.965 & 4.967 & & 4.934 & 4.94 & 4.91 & & 4.945 & 4.9 & 4.9 & & 4.949 & 4.9 & 4.9 & 4.956 \\
\hline 4.953 & 4.950 & 4.956 & 4.949 & 4.945 & 4.967 & 4.916 & 4.940 & 4.923 & 4.959 & 4.952 & 4.9 & 4.942 & 4.934 & 4.942 & 4.989 \\
\hline 4.964 & 4.950 & 4.967 & 4.949 & 4.956 & 4.934 & 4.916 & 4.951 & 4.934 & 4.959 & 4.982 & 4.938 & 4.942 & 4.941 & 4.934 & 4.967 \\
\hline 4.953 & 4.939 & 4.967 & 4.92 & 4.978 & $\begin{array}{l}4.989 \\
\end{array}$ & 4.916 & 4.9 & 4.934 & 4.988 & 4.974 & 4.9 & 4.927 & 4.941 & 4.971 & 4.945 \\
\hline 4.920 & 4.972 & 4.978 & & 4.945 & 4.967 & 4.93 & & 4.945 & 4.9 & 4.95 & 4.9 & 4.927 & 63 & 4.971 & 4.967 \\
\hline 4.931 & 4.950 & 4.978 & 4.938 & 4.956 & 4.978 & 4.927 & 4.951 & 4.934 & 4.967 & 4.982 & 4.982 & 4.949 & 4.949 & 4.942 & 4.978 \\
\hline 4.931 & 4.972 & 4.978 & 4.949 & 4.923 & 4.978 & 4.960 & 4.929 & 4.989 & 4.959 & 4.952 & 4.982 & 4.920 & 4.971 & 4.949 & 4.978 \\
\hline 4.953 & 4.977 & 4.945 & & 4.945 & 4.978 & 4.93 & 4.97 & 4.978 & 4.967 & 4.95 & 4.9 & 4.927 & 4.963 & 4.927 & 4.967 \\
\hline 4.975 & 4.961 & 4.956 & 4.9 & 4.956 & 4.94 & 4.94 & & 4.956 & 4.92 & 4.93 & 4.9 & 4.920 & 4.971 & 4.913 & 4.972 \\
\hline 4.969 & 4.977 & 4.967 & & 4.956 & 4.956 & 4.949 & 4.951 & 4.989 & 4.974 & 4.923 & 4.974 & 4.927 & & 4.923 & 4.967 \\
\hline 4.953 & & & & 4.967 & 4.989 & 4.971 & 4.984 & 4.956 & 4.974 & 4.938 & 4.9 & & & & \\
\hline & & & & & & & & 4.967 & 4.959 & & 4.989 & & & & \\
\hline & & & & & & & & 4.956 & & & 4.974 & & & & \\
\hline
\end{tabular}

Note: Each row represents an individual coil measurement, with the first row (coil measurement 1) corresponding to the unpainted end of the spring. To arrive at the plot in Figure 6, Specimens \#1, \#2, \#3, \#4, and \#8 were flipped. Through this method, the plot represents the continuous profile of the entire spring. 
APPENDIX B. ANSYS CAPSULE DESIGN REPORTS 


\section{APPENDIX B. ANSYS CAPSULE DESIGN REPORTS}

\section{Specimen 1, 330C, BOI ANSYS Results}

\section{BOUNDARY CONDI TI ONS}

Heat transfer coef $\mathrm{fici}$ ent $=47100 . \mathrm{W} \mathrm{na} \cdot{ }^{\circ} \mathrm{C}$

Bul $\mathrm{k} \mathrm{cool}$ ant temperat ure $=52.0^{\circ} \mathrm{C}$

\section{HEAT GENERATI ON}

$$
\text { Part }
$$

1) Housi ng

3) Hol der

5) Endcap. 1

7) Endcap. 2

9) Buf fer

10) Ther mol der

11) Ther $m$

12) Spring. 1

14) Spring. 2

16) Spri ng. 3

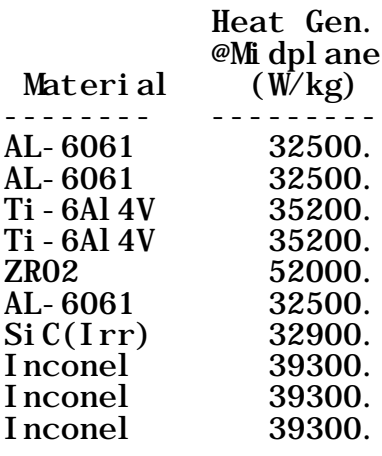

\section{CAPSULE TEMPERATURE SUMMARY}

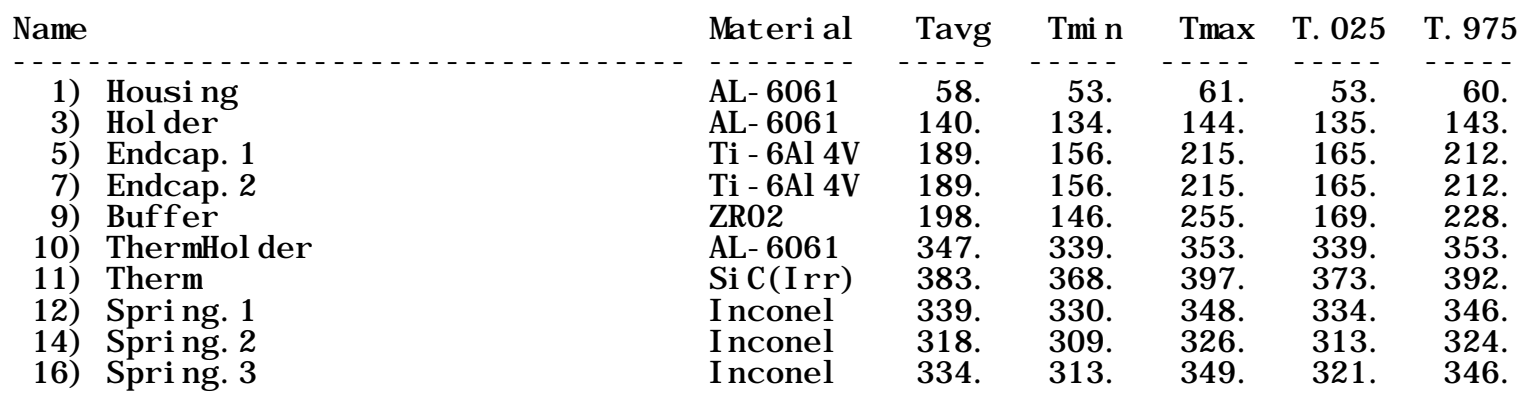

PROPERTY SUMMARY AT THE AVERAGE PART TEMPERATURE

\section{Name}
1) Housing
3) Hol der
5) Endcap. 1
7) Endcap. 2
9) Buf fer
10) Ther mHol der
11) Therm
12) Spring. 1
14) Spring. 2
16) Spring. 3

\begin{tabular}{|c|c|c|c|}
\hline Materi al & $\begin{array}{l}\text { Ther nal } \\
\text { Cond. } \\
\text { ( W } \mathrm{m} \cong \mathrm{C})\end{array}$ & $\begin{array}{l}\text { Ther mal } \\
\text { Exp. } \\
\text { Coef } \mathrm{f} . \\
\left(\text { und m }{ }^{\circ} \mathrm{C}\right)\end{array}$ & $\begin{array}{l}\text { Emi s } \\
(--.)\end{array}$ \\
\hline & & & \\
\hline L- 6061 & 166. 449 & 24. 21 & 0.050 \\
\hline-6061 & 936 & 24. 29 & 0.05 \\
\hline $\mathrm{Ti}-6 \mathrm{Al} 4 \mathrm{~V}$ & 290 & 0.00 & 0.320 \\
\hline Ti - 6Al 4V & 10. 289 & 0.00 & 0.320 \\
\hline ZRO2 & 1. 825 & 7. 80 & 0.800 \\
\hline L- 6061 & 176. 000 & 0.00 & 0.060 \\
\hline$C(I r r)$ & 4. 974 & & 0.900 \\
\hline ' & 16. 035 & 13. & 0.925 \\
\hline 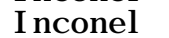 & 15.729 & 13. 48 & 0.925 \\
\hline I nconel & 15. 962 & 13. 56 & 0.925 \\
\hline
\end{tabular}




\section{Specimen 1, 330C, EOI ANSYS Results}

\section{BOUNDARY CONDI TI ONS}

Heat transf er coeffici ent $=47100 . \mathrm{W} \mathrm{n}^{2} \cdot{ }^{\circ} \mathrm{C}$
Bul $\mathrm{k}$ cool ant temperat ure $=52.0^{\circ} \mathrm{C}$

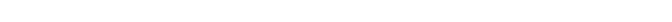

HEAT GENERATI ON

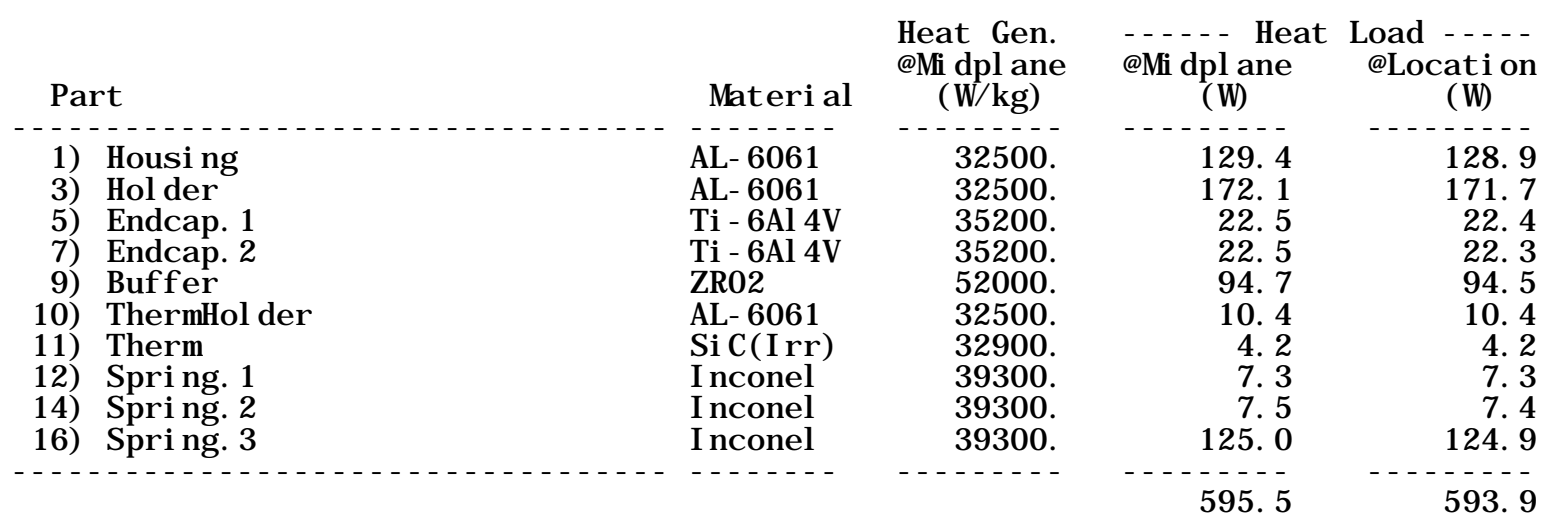

\section{CAPSULE TEMPERATURE SUMMARY}

\begin{tabular}{|c|c|c|c|c|c|c|c|}
\hline Name & & Materi al & Tavg & Tmin $n$ & Trax & T. 025 & T. 975 \\
\hline - - - & Hen & - - - - - - & 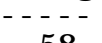 & & & & \\
\hline 1) & $\begin{array}{l}\text { Housi ng } \\
\text { Hol der }\end{array}$ & $\begin{array}{l}\text { AL- } 6061 \\
\text { AL- } 6061\end{array}$ & $\begin{array}{r}58 . \\
140 .\end{array}$ & $\begin{array}{r}53 . \\
135 .\end{array}$ & $\begin{array}{r}61 . \\
144 .\end{array}$ & $\begin{array}{r}53 . \\
136 .\end{array}$ & $\begin{array}{r}60 \\
144\end{array}$ \\
\hline 5) & Endcap. 1 & $\mathrm{Ti}-6 \mathrm{Al} 4 \mathrm{~V}$ & 189. & 156. & 215 . & 165. & \\
\hline & Endcap. 2 & Ti - 6Al 4V & 189. & 156. & 215. & 166. & \\
\hline 9) & Buf f er & ZRO2 & 199. & 147. & 253. & 170. & \\
\hline 10) & Ther mHol der & AL- 6061 & 341. & 333. & 347. & 333. & \\
\hline 11) & Ther m & $\mathrm{Si} C(\mathrm{I} r \mathrm{r})$ & 377. & 362. & 391. & 366. & \\
\hline 12) & Spring. 1 & I nconel & & & 344. & & \\
\hline 14 & Spri ng. 2 & I nconel & & 30 & 319. & 30 & \\
\hline 1 & Spr i ng. 3 & I nconel & 327. & 305. & 343. & 314. & \\
\hline
\end{tabular}

PROPERTY SUMMARY AT THE AVERAGE PART TEMPERATURE

Nane
1) Housi ng
3) Hol der
5) Endcap. 1
7) Endcap. 2
9) Buf fer
10) Ther nHol der
11) Ther m
12) Spri ng. 1
14) Spri ng. 2
16) Spri ng. 3

\begin{tabular}{|c|c|c|c|}
\hline Materi al & $\begin{array}{l}\text { Ther nal } \\
\text { Cond. } \\
\text { ( W m } \stackrel{0}{ } \text { ) }\end{array}$ & $\begin{array}{l}\text { Ther mal } \\
\text { Exp. } \\
\text { Coef } \mathrm{f} \text {. } \\
\left(\mu \mathrm{m} \text { m }{ }^{\circ} \mathrm{C}\right)\end{array}$ & $\begin{array}{l}\text { Em s } \\
(---)\end{array}$ \\
\hline$A \mathrm{AL}-6061$ & 166450 & 2421 & $-\cdots$ \\
\hline AL- 6061 & 174. 952 & 24. 29 & 0.050 \\
\hline Ti - 6Al 4V & 10. 294 & 0.00 & 0. 320 \\
\hline $\mathrm{Ti}-6 \mathrm{Al} 4 \mathrm{~V}$ & 10. 293 & 0.00 & 0.320 \\
\hline ZRO2 & 1. 825 & 7. 80 & 0.800 \\
\hline AL- 6061 & 176. 000 & 0.00 & 0.059 \\
\hline Si C(Irr) & 4. 976 & 3. 48 & 0. 900 \\
\hline I nconel & 15. 937 & 13. 56 & 0.925 \\
\hline & 15. 619 & 13. & 0.925 \\
\hline nconel & 15. 856 & 13. 5 & 0.925 \\
\hline
\end{tabular}




\section{Specimen 2, 230C, ANSYS Results}

\section{BOUNDARY CONDI TI ONS}

Heat transfer coef $\mathrm{fici}$ ent $=47100 . \mathrm{W} \mathrm{na} \cdot{ }^{\circ} \mathrm{C}$

Bul $\mathrm{k} \mathrm{cool}$ ant temperat ure $=52.0{ }^{\circ} \mathrm{C}$

\section{HEAT GENERATI ON}

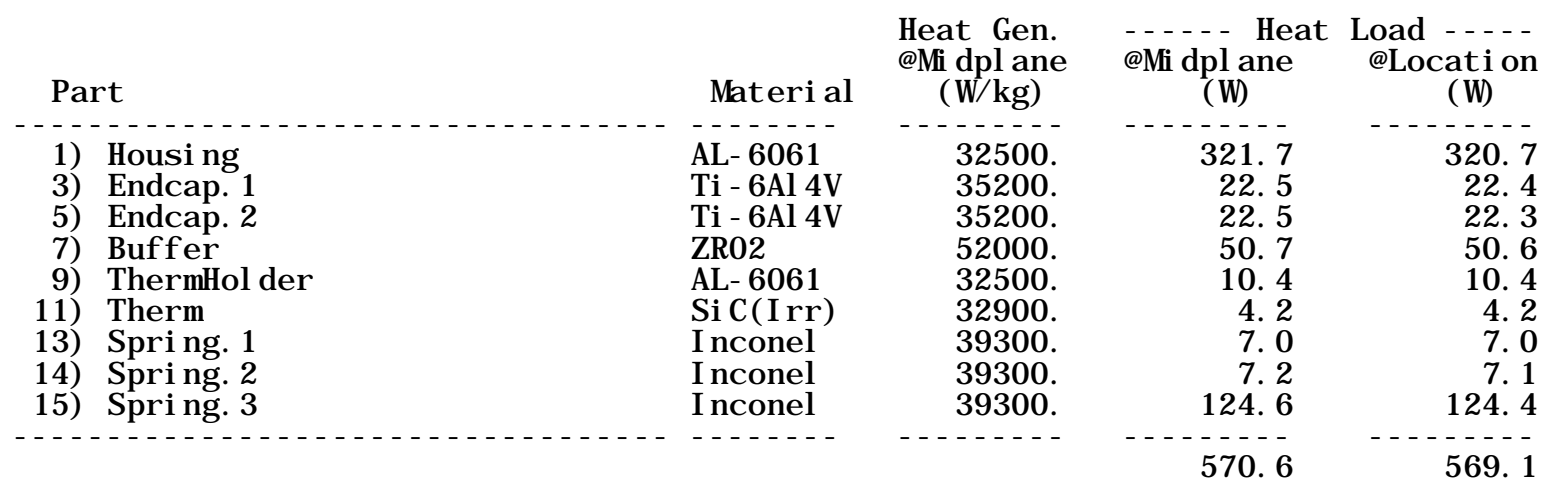

\section{CAPSULE TEMPERATURE SUMMARY}

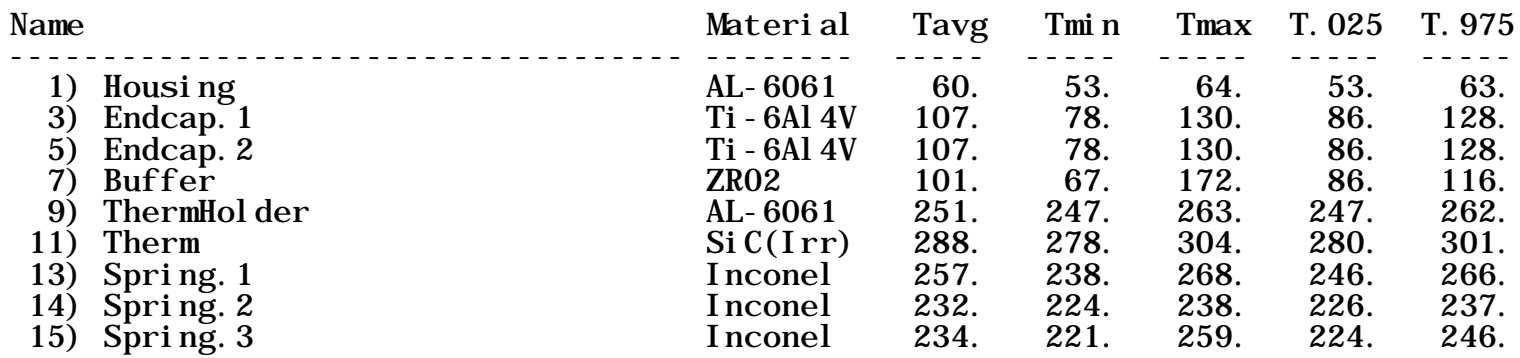

PROPERTY SUMMARY AT THE AVERAGE PART TEMPERATURE

\section{Name}

1) Housing

3) Endcap. 1

5) Endcap. 2

7) Buffer

9) Ther mol der

11) Ther $m$

13) Spring. 1

14) Spring. 2

15) Spring. 3

\begin{tabular}{|c|c|c|c|}
\hline at eri al & $\begin{array}{l}\text { Ther mal } \\
\text { Cond. } \\
(\mathrm{W} \text { mo } \mathrm{C})\end{array}$ & $\begin{array}{l}\text { Exp. } \\
\text { Coef } \mathrm{f} . \\
\left(\mu \mathrm{m} \mathrm{m}^{\circ} \mathrm{C}\right)\end{array}$ & $\begin{array}{c}\text { Emi s } \\
(-\ldots)\end{array}$ \\
\hline $\begin{array}{l}\mathrm{AL}-6061 \\
\mathrm{Ti}-6 \mathrm{Al} 4 \mathrm{~V} \\
\mathrm{Ti}-6 \mathrm{Al} 4 \mathrm{~V} \\
\mathrm{ZRO} \\
\mathrm{AL}-6061 \\
\mathrm{Si} \mathrm{C}(\mathrm{I} \mathrm{rr}) \\
\text { I nconel } \\
\text { I nconel } \\
\text { I nconel }\end{array}$ & $\begin{array}{r}166.667 \\
8.850 \\
8.847 \\
1.801 \\
176.000 \\
5.942 \\
14.860 \\
14.500 \\
14.534\end{array}$ & $\begin{array}{r}0.00 \\
0.00 \\
0.00 \\
7.80 \\
0.00 \\
\text { 3. } 23 \\
13.22 \\
13.11 \\
13.12\end{array}$ & $\begin{array}{l}0.050 \\
0.320 \\
0.320 \\
0.800 \\
0.054 \\
0.900 \\
0.925 \\
0.925 \\
0.925\end{array}$ \\
\hline
\end{tabular}




\section{Specimen 3, 230C, ANSYS Results}

\section{BOUNDARY CONDI TI ONS}

Heat transfer coef $\mathrm{fici}$ ent $=47100 . \mathrm{W} \mathrm{n}^{2} \cdot{ }^{\circ} \mathrm{C}$

Bul $\mathrm{k} \mathrm{cool}$ ant temperat ure $=52.0^{\circ} \mathrm{C}$

HEAT GENERATI ON

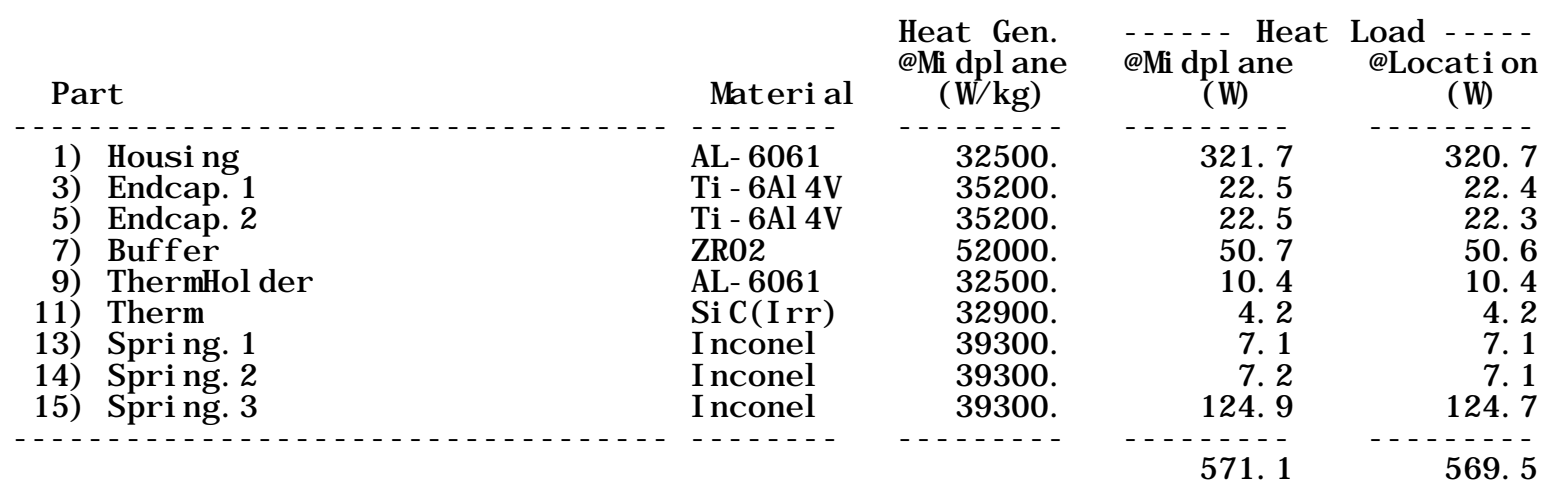

CAPSULE TEMPERATURE SUMMARY

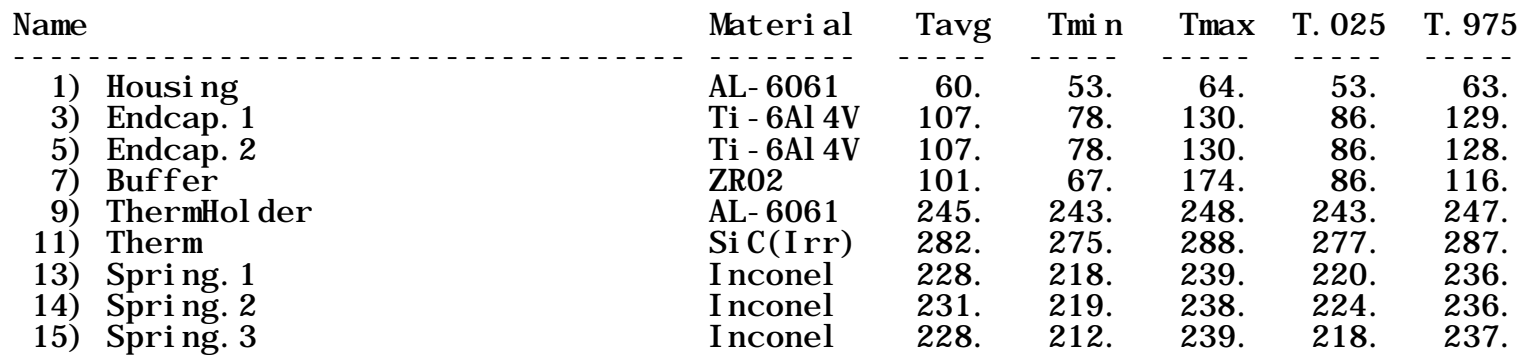

PROPERTY SUMMARY AT THE AVERAGE PART TEMPERATURE

\section{Name}

1) Housi ng

3) Endcap. 1

5) Endcap. 2

7) Buf fer

9) Ther mHol der

11) Therm

13) Spring. 1

14) Spring. 2

15) Spring. 3

\begin{tabular}{|c|c|c|c|}
\hline Mat eri al & $\begin{array}{l}\text { Ther mal } \\
\text { Cond. } \\
\left(\mathrm{W} \mathrm{m}^{\circ} \mathrm{C}\right)\end{array}$ & $\begin{array}{l}\text { Ther mal } \\
\text { Exp. } \\
\text { Coef } f \\
\left(\mu \mathrm{m} \mathrm{m}^{\circ} \mathrm{C}\right)\end{array}$ & $\begin{array}{c}\operatorname{Eni} s \\
(-\cdots)\end{array}$ \\
\hline $\begin{array}{l}\text { AL- 6061 } \\
\text { Ti - 6Al 4V } \\
\text { Ti - 6Al 4V } \\
\text { ZRO2 } \\
\text { AL-6061 } \\
\text { Si C( I r r ) } \\
\text { I nconel } \\
\text { I nconel } \\
\text { I nconel }\end{array}$ & $\begin{array}{r}166.668 \\
8.850 \\
8.847 \\
1.801 \\
176.000 \\
5.880 \\
14.438 \\
14.480 \\
14.442\end{array}$ & $\begin{array}{r}0.00 \\
0.00 \\
0.00 \\
7.80 \\
0.00 \\
3.21 \\
13.09 \\
13.10 \\
13.09\end{array}$ & $\begin{array}{l}0.050 \\
0.320 \\
0.320 \\
0.800 \\
0.054 \\
0.900 \\
0.925 \\
0.925 \\
0.925\end{array}$ \\
\hline
\end{tabular}




\section{Specimen 4, 230C, ANSYS Results}

\section{BOUNDARY CONDI TI ONS}

Heat transfer coef $\mathrm{fici}$ ent $=47100 . \mathrm{W} \mathrm{na} \cdot{ }^{\circ} \mathrm{C}$

Bul $\mathrm{k} \mathrm{cool}$ ant temperat ure $=52.0^{\circ} \mathrm{C}$

\section{HEAT GENERATI ON}

\begin{tabular}{|c|c|}
\hline \multicolumn{2}{|c|}{ Part } \\
\hline $\begin{array}{l}\text { 1) } \\
3 \text { ) } \\
5 \text { ) } \\
7 \text { ) } \\
\text { 9) } \\
\text { 11) } \\
\text { 12) } \\
\text { 13) } \\
\text { 14) }\end{array}$ & $\begin{array}{l}\text { Housi ng } \\
\text { Endcap. } 1 \\
\text { Endcap. } 2 \\
\text { Buf f er. } 1 \\
\text { Ther mHol der } \\
\text { Ther m } \\
\text { Spri ing. } 1 \\
\text { Spri ing. } 2 \\
\text { Spri ing. } 3\end{array}$ \\
\hline
\end{tabular}

\begin{tabular}{|c|c|}
\hline Mat er i al & $\begin{array}{l}\text { Heat Gen. } \\
\text { (dM dpl ane } \\
(\text { W kg) }\end{array}$ \\
\hline $\begin{array}{l}\text { AL- 6061 } \\
\mathrm{Ti}-6 \mathrm{Al} \text { 4V } \\
\mathrm{Ti}-6 \mathrm{Al} \text { 4V } \\
\mathrm{ZRO2} \\
\mathrm{AL}-6061 \\
\mathrm{Si} \mathrm{C}(\mathrm{I} \mathrm{rr} \text { ) } \\
\text { I nconel } \\
\text { Inconel } \\
\text { I nconel }\end{array}$ & \\
\hline
\end{tabular}

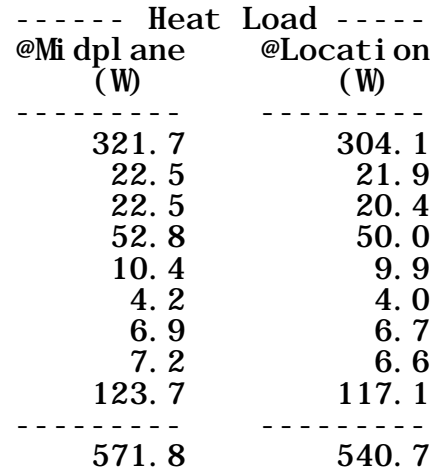

CAPSULE TEMPERATURE SUMMARY

\begin{tabular}{|c|c|c|c|c|c|c|c|}
\hline Name & & Mat er i al & Tavg & Tmi $n$ & $\operatorname{Trax}$ & T. 025 & Т. 975 \\
\hline $\begin{array}{r}\text { 1) } \\
3) \\
5) \\
7) \\
9) \\
11) \\
12) \\
13) \\
14)\end{array}$ & $\begin{array}{l}\text { Housi ng } \\
\text { Endcap. } 1 \\
\text { Endcap. } 2 \\
\text { Buf fer. } 1 \\
\text { Ther nHol der } \\
\text { Ther m } \\
\text { Spr i ng. } 1 \\
\text { Spring. } 2 \\
\text { Spri ng. } 3\end{array}$ & $\begin{array}{l}\mathrm{AL}-6061 \\
\mathrm{Ti}-6 \mathrm{Al} 4 \mathrm{~V} \\
\mathrm{Ti}-6 \mathrm{Al} 4 \mathrm{~V} \\
\mathrm{ZRO2} \\
\mathrm{AL}-6061 \\
\mathrm{Si} \mathrm{C}(\mathrm{I} \mathrm{rr}) \\
\text { I nconel } \\
\text { I nconel } \\
\text { I nconel }\end{array}$ & $\begin{array}{r}60 . \\
107 . \\
103 . \\
99 . \\
247 . \\
284 . \\
248 . \\
223 . \\
234 .\end{array}$ & $\begin{array}{r}53 . \\
78 . \\
76 . \\
65 . \\
243 . \\
273 . \\
238 . \\
209 . \\
216 .\end{array}$ & $\begin{array}{l}63 . \\
129 . \\
125 . \\
156 . \\
256 . \\
301 . \\
262 . \\
231 . \\
250 .\end{array}$ & $\begin{array}{r}53 . \\
87 . \\
84 . \\
85 . \\
243 . \\
277 . \\
239 . \\
213 . \\
222 .\end{array}$ & $\begin{array}{l}63 . \\
128 . \\
123 . \\
117 . \\
255 . \\
296 . \\
260 . \\
230 . \\
246 .\end{array}$ \\
\hline
\end{tabular}

PROPERTY SUMMARY AT THE AVERAGE PART TEMPERATURE

\section{Name}
1) Housing
3) Endcap. 1
5) Endcap. 2
7) Buf fer. 1
9) Ther nHol der
11) Ther $m$
12) Spring. 1
13) Spring. 2
14) Spring. 3

\begin{tabular}{|c|c|c|c|}
\hline Materi al & $\begin{array}{l}\text { Ther mal } \\
\text { Cond. } \\
\text { ( } \mathrm{W} \mathrm{m} \text { o } \mathrm{C})\end{array}$ & $\begin{array}{l}\text { Ther mal } \\
\text { Exp. } \\
\text { Coef } f \\
\left(\mu \mathrm{m} \mathrm{m}^{\circ} \mathrm{C}\right)\end{array}$ & 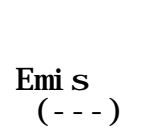 \\
\hline $\begin{array}{l}\text { AL- 6061 } \\
\text { Ti - 6Al 4V } \\
\text { Ti - 6Al 4V } \\
\text { ZRO2 } \\
\text { AL-6061 } \\
\text { Si C( I r r r ) } \\
\text { I nconel } \\
\text { I nconel } \\
\text { I nconel }\end{array}$ & $\begin{array}{r}166.601 \\
8.845 \\
8.791 \\
1.800 \\
176.000 \\
5.900 \\
14.735 \\
14.366 \\
14.535\end{array}$ & $\begin{array}{r}0.00 \\
0.00 \\
0.00 \\
7.80 \\
0.00 \\
3.22 \\
13.18 \\
13.07 \\
13.12\end{array}$ & $\begin{array}{l}0.050 \\
0.320 \\
0.320 \\
0.800 \\
0.054 \\
0.900 \\
0.925 \\
0.925 \\
0.925\end{array}$ \\
\hline
\end{tabular}




\section{Specimen 5, 230C, ANSYS Results}

\section{BOUNDARY CONDI TI ONS}

Heat transfer coeffi ci ent $=47100 . \mathrm{W} \mathrm{m}^{2} \cdot{ }^{\circ} \mathrm{C}$

Bul $\mathrm{k} \mathrm{cool}$ ant temperat ure $=52.0^{\circ} \mathrm{C}$

\section{HEAT GENERATI ON}

\begin{tabular}{|c|c|c|c|c|c|}
\hline \multicolumn{2}{|c|}{ Part } & Mat eri al & $\begin{array}{l}\text { Heat Gen. } \\
\text { GM dpl ane } \\
(W \mathrm{~kg})\end{array}$ & (M) dpl ane & $\begin{array}{c}\text { Load } \ldots \text {. } \\
\text { (d)ocat i on } \\
\text { ( }\end{array}$ \\
\hline $\begin{array}{r}\text { 1) } \\
3 \text { ) } \\
5 \text { ) } \\
7 \text { ) } \\
9 \text { ) } \\
11) \\
12) \\
13) \\
14)\end{array}$ & $\begin{array}{l}\text { Housi ng } \\
\text { Endcap. } 1 \\
\text { Endcap. } 2 \\
\text { Buf f er. } 1 \\
\text { Ther mHol der } \\
\text { Ther m } \\
\text { Spring. } 1 \\
\text { Spring. } 2 \\
\text { Spring. } 3\end{array}$ & $\begin{array}{l}\text { AL- 6061 } \\
\text { Ti - 6Al 4V } \\
\text { Ti - 6Al 4V } \\
\text { ZRO2 } \\
\text { AL-6061 } \\
\text { Si C(I r r }) \\
\text { I nconel } \\
\text { I nconel } \\
\text { I nconel }\end{array}$ & $\begin{array}{l}32500 . \\
35200 . \\
35200 . \\
52000 . \\
32500 . \\
32900 . \\
39300 . \\
39300 . \\
39300 .\end{array}$ & $\begin{array}{r}321.7 \\
22.5 \\
22.5 \\
52.8 \\
10.4 \\
4.2 \\
6.9 \\
7.2 \\
123.6\end{array}$ & $\begin{array}{r}304.1 \\
21.9 \\
20.4 \\
50.0 \\
9.9 \\
4.0 \\
6.7 \\
6.6 \\
117.0\end{array}$ \\
\hline & & & & 571. 8 & 540.7 \\
\hline
\end{tabular}

CAPSULE TEMPERATURE SUMMARY

\begin{tabular}{|c|c|c|c|c|c|c|c|}
\hline Name & & Materi al & Tavg & Trm $n$ & $\operatorname{Tn} m x$ & T. 025 & T. 975 \\
\hline $\begin{array}{r}\text { 1) } \\
3) \\
5) \\
7) \\
9) \\
11) \\
12) \\
13) \\
14)\end{array}$ & $\begin{array}{l}\text { Housi ng } \\
\text { Endcap. } 1 \\
\text { Endcap. } 2 \\
\text { Buf f er. } 1 \\
\text { Ther nHol der } \\
\text { Ther m } \\
\text { Spri ing. } 1 \\
\text { Spring. } 2 \\
\text { Spri ng. } 3\end{array}$ & $\begin{array}{l}\text { AL- 6061 } \\
\text { Ti - 6Al 4V } \\
\text { Ti - 6Al 4V } \\
\text { ZRO2 } \\
\text { AL-6061 } \\
\text { Si C( I rr }) \\
\text { I nconel } \\
\text { I nconel } \\
\text { I nconel }\end{array}$ & $\begin{array}{r}60 . \\
107 . \\
103 . \\
99 . \\
248 . \\
285 . \\
255 . \\
218 . \\
235 .\end{array}$ & $\begin{array}{r}53 . \\
78 . \\
76 . \\
65 . \\
237 . \\
268 . \\
247 . \\
211 . \\
208 .\end{array}$ & $\begin{array}{l}63 . \\
129 . \\
125 . \\
164 . \\
262 . \\
307 . \\
262 . \\
223 . \\
260 .\end{array}$ & $\begin{array}{r}53 . \\
87 . \\
84 . \\
86 . \\
237 . \\
271 . \\
249 . \\
212 . \\
214 .\end{array}$ & $\begin{array}{r}63 . \\
128 . \\
123 . \\
116 . \\
262 . \\
303 . \\
260 . \\
223 .\end{array}$ \\
\hline
\end{tabular}

PROPERTY SUMMARY AT THE AVERAGE PART TEMPERATURE

1) Housing
3) Endcap. 1
5) Endcap. 2
7) Buf f er. 1
9) Ther nhol der
11) Therm
12) Spri ing. 1
13) Spring. 2
14) Spri ing. 3
Updat e of ANSYS syst em successf ul...

\begin{tabular}{|c|c|c|c|}
\hline Materi al & $\begin{array}{l}\text { Ther mal } \\
\text { Cond. } \\
\text { ( W m } \mathrm{o} \text { C) }\end{array}$ & $\begin{array}{l}\text { Ther mal } \\
\text { Exp. } \\
\text { Coef } \mathrm{f} \\
\left(\mu \mathrm{m} \mathrm{m}^{\circ}{ }^{\circ} \mathrm{C}\right)\end{array}$ & $\begin{array}{c}\text { Emi s } \\
(---) ~\end{array}$ \\
\hline $\begin{array}{l}\text { AL- 6061 } \\
\text { Ti - 6Al 4V } \\
\text { Ti - 6Al 4V } \\
\text { ZRO2 } \\
\text { AL-6061 } \\
\text { Si C(I r r }) \\
\text { I nconel } \\
\text { I nconel } \\
\text { I nconel }\end{array}$ & $\begin{array}{r}\text { 166. } 601 \\
\text { 8. } 845 \\
8.790 \\
1.800 \\
176.000 \\
5.906 \\
14.824 \\
14.299 \\
14.542\end{array}$ & $\begin{array}{r}0.00 \\
0.00 \\
0.00 \\
7.80 \\
0.00 \\
3.22 \\
13.21 \\
13.04 \\
13.12\end{array}$ & $\begin{array}{l}0.050 \\
0.320 \\
0.320 \\
0.800 \\
0.054 \\
0.900 \\
0.925 \\
0.925 \\
0.925\end{array}$ \\
\hline
\end{tabular}




\section{Specimen 6, 330C, BOI ANSYS Results}

\section{BOUNDARY CONDI TI ONS}

Heat transfer coef $\mathrm{fi} \mathrm{ci}$ ent $=47100 . \mathrm{W} \mathrm{nz} \cdot{ }^{\circ} \mathrm{C}$

Bul $\mathrm{k} \mathrm{cool} \mathrm{ant} \mathrm{temperat} \mathrm{ure}=52.0^{\circ} \mathrm{C}$

\section{HEAT GENERATI ON}

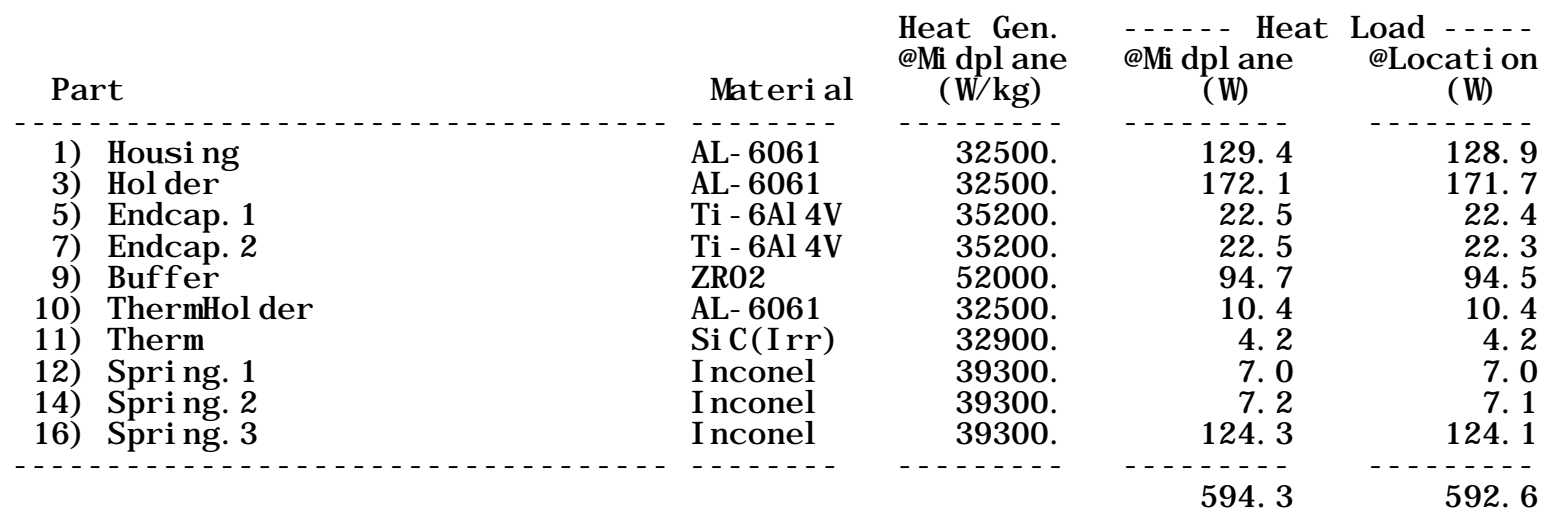

CAPSULE TEMPERATURE SUMMARY

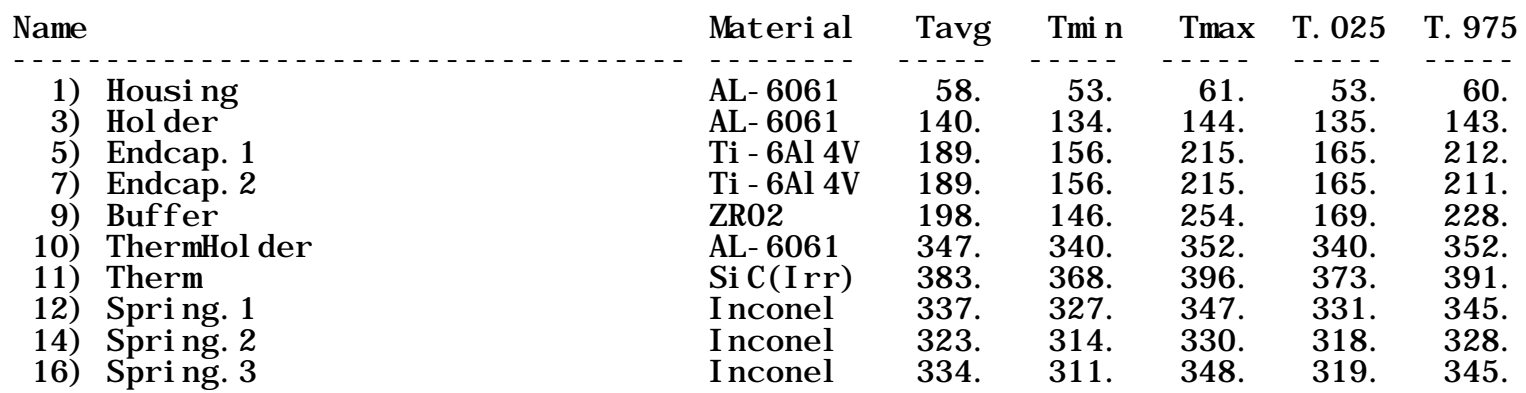

PROPERTY SUMMARY AT THE AVERAGE PART TEMPERATURE

Name
1) Housi ng
5) Hol der
7) Endcap. 1
9) Endcap. 2
10) The fer
11) Ther mol der
12) Spri ng. 1
14) Spri ng. 2
16) Spri ng. 3

\begin{tabular}{|c|c|c|c|}
\hline vat eri al & $\begin{array}{l}\text { Ther nal } \\
\text { Cond. } \\
\text { ( W m } \cong \mathrm{C})\end{array}$ & $\begin{array}{l}\text { Ther mal } \\
\text { Exp. } \\
\text { Coef f . } \\
\left.\text { ( } \text { um m m }{ }^{\circ} \mathrm{C}\right)\end{array}$ & $\begin{array}{l}\text { Emi } s \\
(-\ldots)\end{array}$ \\
\hline & $-\ldots$ & & $-\ldots$ \\
\hline$A L-6061$ & ). 449 & 24. 21 & 0.05 \\
\hline 6061 & 174. 936 & 24. 29 & 0.05 \\
\hline Ti - 6Al 4V & 10. 291 & 0.00 & 0.320 \\
\hline Ti - 6Al 4V & 10. 287 & 0.00 & 0.320 \\
\hline & & 7. 80 & 0.800 \\
\hline 6061 & 176.000 & 0.00 & 0.060 \\
\hline$(\operatorname{lrr})$ & 4. & 3. 50 & 0.900 \\
\hline I nconel & 15. 996 & 13. 58 & 0.925 \\
\hline onel & כצוא. & 13. 51 & \\
\hline one & 15. 957 & 13. 56 & 0.925 \\
\hline
\end{tabular}




\section{Specimen 6, 330C, EOI ANSYS Results}

\section{BOUNDARY CONDI TI ONS}

Heat transfer coef $\mathrm{fici}$ ent $=47100 . \mathrm{W} \mathrm{na} \cdot{ }^{\circ} \mathrm{C}$

Bul $\mathrm{k} \mathrm{cool}$ ant temperat ure $=52.0{ }^{\circ} \mathrm{C}$

\section{HEAT GENERATI ON}

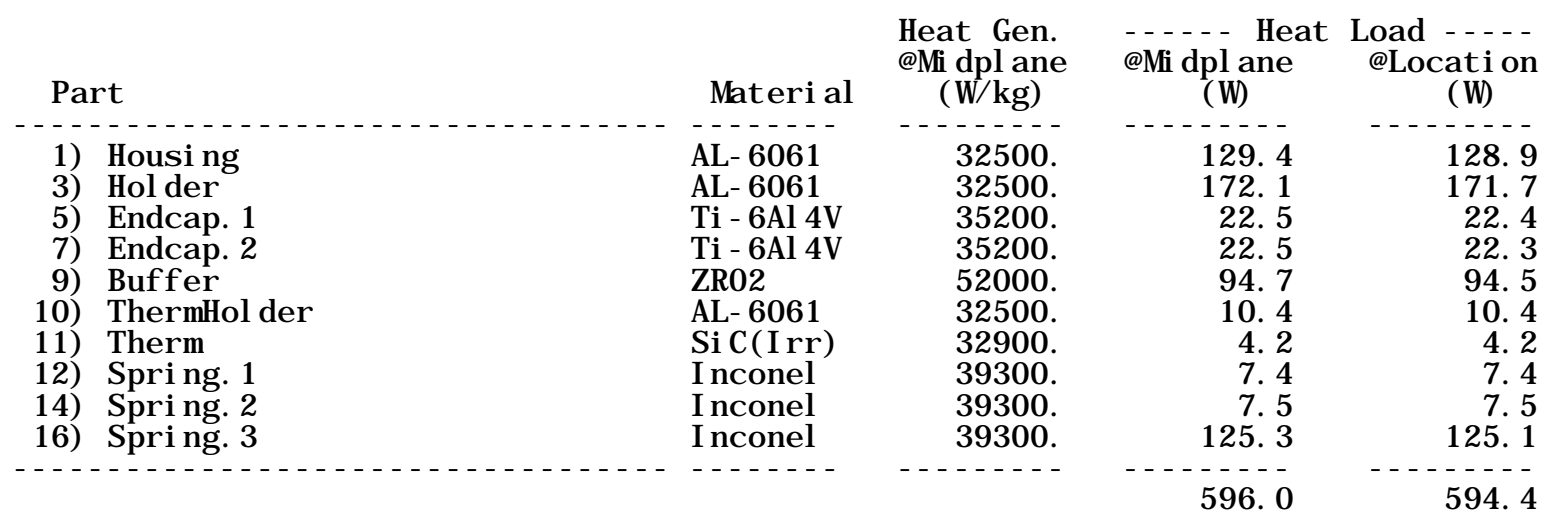

CAPSULE TEMPERATURE SUMMARY

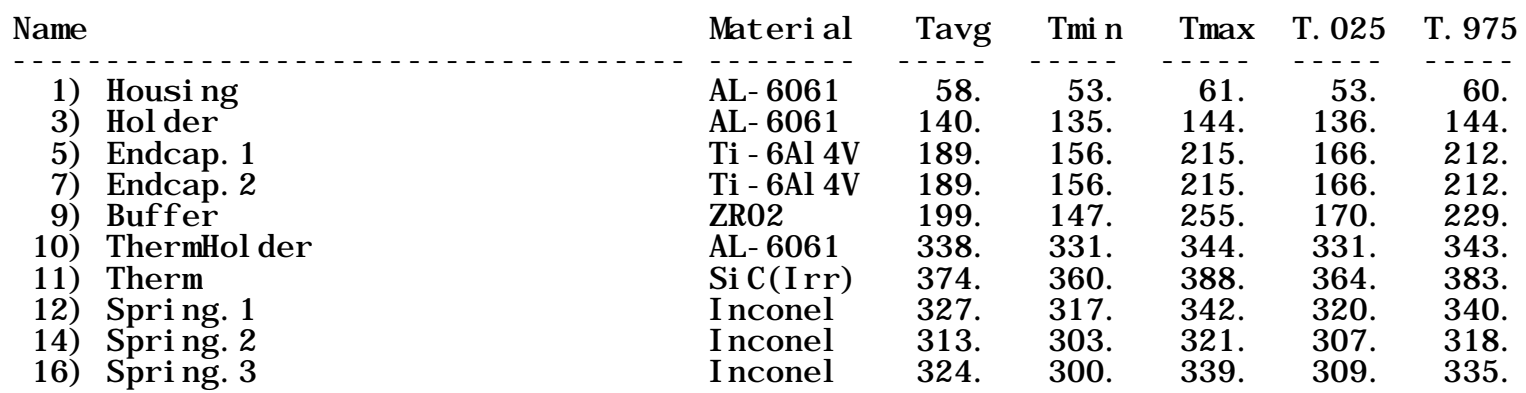

PROPERTY SUMMARY AT THE AVERAGE PART TEMPERATURE

\begin{tabular}{|c|c|c|c|c|c|}
\hline Name & & Mat er i al & $\begin{array}{l}\text { Ther nal } \\
\text { Cond. } \\
\text { ( W m } \mathrm{o} \text { C) }\end{array}$ & $\begin{array}{l}\text { Ther nal } \\
\text { Exp. } \\
\text { Coef } \mathrm{f} \text {. } \\
\left(\mu \mathrm{m} \mathrm{m}^{\circ} \mathrm{C}\right)\end{array}$ & $\begin{array}{l}\text { Emi } s \\
(---)\end{array}$ \\
\hline---1 & 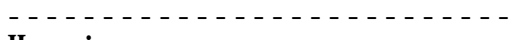 & - - - - - - - & 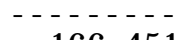 & & \\
\hline 1) & Housi ng & AL- 6061 & 166. 451 & 24. 21 & $\begin{array}{l}0.050 \\
0.050\end{array}$ \\
\hline 5) & $\begin{array}{l}\text { Hol der } \\
\text { Endcap. } 1\end{array}$ & $\begin{array}{l}\mathrm{AL}-6061 \\
\mathrm{Ti}-6 \mathrm{Al} 4 \mathrm{~V}\end{array}$ & $\begin{array}{r}1 / 4.958 \\
10.295\end{array}$ & $\begin{array}{r}24.29 \\
0.00\end{array}$ & $\begin{array}{l}0.050 \\
0.320\end{array}$ \\
\hline 7) & Endcap. 2 & $\mathrm{Ti}-6 \mathrm{Al} 4 \mathrm{~V}$ & 10. 292 & 0.00 & 0.320 \\
\hline 9) & Buf f er & ZRO2 & 1. 825 & 7. 80 & 0.800 \\
\hline 10) & Ther $\mathrm{mHol}$ der & $A L-6061$ & 176. 000 & 0.00 & 0.059 \\
\hline 11) & Ther $\mathrm{m}$ & $\mathrm{Si} C(I r r)$ & 4. 977 & 3. 47 & 0.900 \\
\hline 12) & Spri ng. 1 & I nconel & 15. 864 & 13. 53 & 0.925 \\
\hline 14) & Spr i ng. 2 & I nconel & 15. 651 & 13. 46 & 0.925 \\
\hline 16) & Spri ng. 3 & I nconel & 15.816 & 13. 51 & 0.925 \\
\hline
\end{tabular}




\section{Specimen 7, 330C, BOI ANSYS Results}

\section{BOUNDARY CONDI TI ONS}

Heat transfer coef $\mathrm{fi} \mathrm{ci} \mathrm{ent}=47100 . \mathrm{W} \mathrm{na} \cdot{ }^{\circ} \mathrm{C}$

Bul $\mathrm{k} \mathrm{cool}$ ant temperat ure $=52.0{ }^{\circ} \mathrm{C}$

\section{HEAT GENERATI ON}

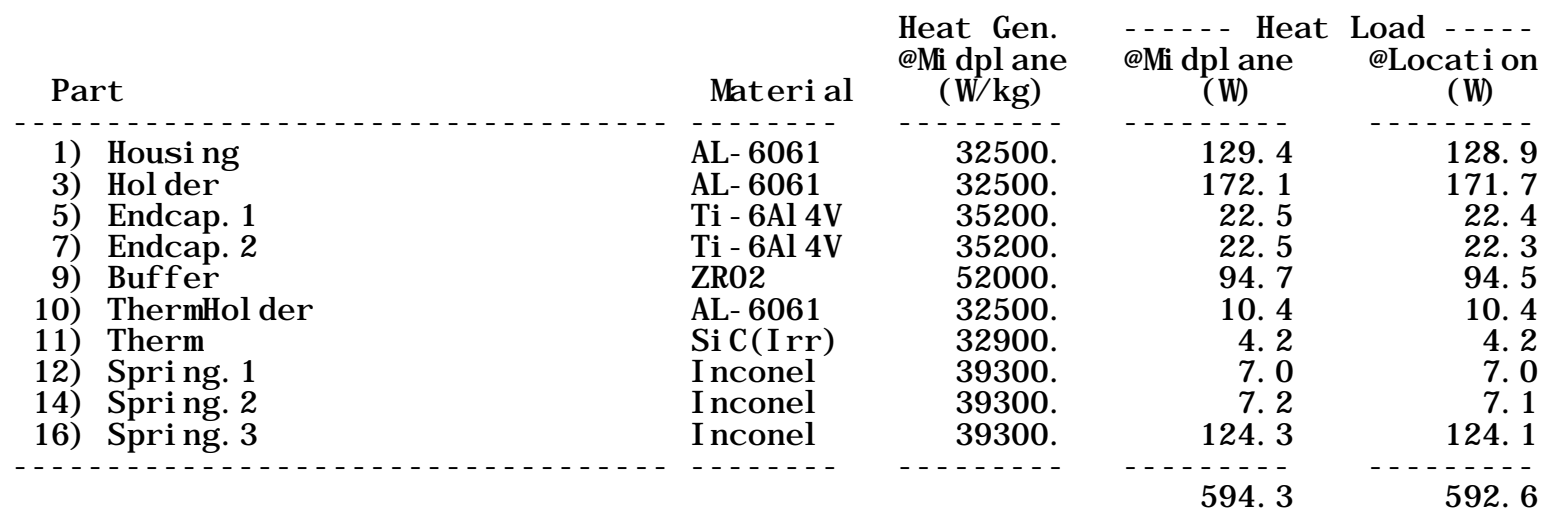

CAPSULE TEMPERATURE SUMMARY

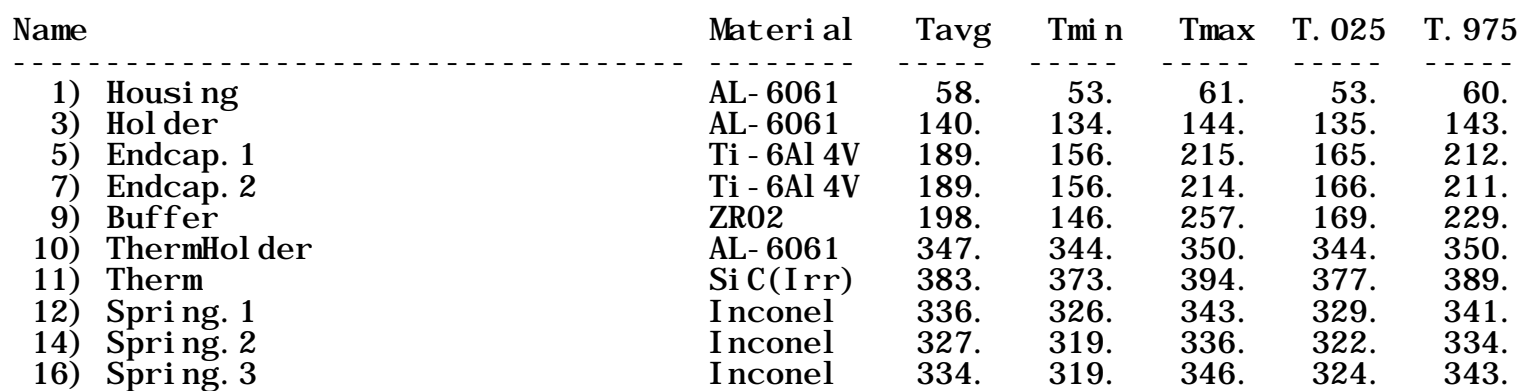

PROPERTY SUMMARY AT THE AVERAGE PART TEMPERATURE

\begin{tabular}{|c|c|c|c|c|c|}
\hline Nare & & Materi al & $\begin{array}{l}\text { Ther n⿴l } \\
\text { Cond. } \\
\text { ( W } \mathrm{m} \cong \mathrm{C})\end{array}$ & $\begin{array}{l}\text { Ther nal } \\
\text { Exp. } \\
\text { Coef } \mathrm{f} \text {. } \\
\left(\mu \mathrm{m} \mathrm{m}^{\circ} \mathrm{C}\right)\end{array}$ & $\begin{array}{l}\text { Emi s } \\
(---)\end{array}$ \\
\hline & - & & & & \\
\hline 1) & $\begin{array}{l}\text { Housing } \\
\text { Hol der }\end{array}$ & $\begin{array}{l}A L-6061 \\
A L-6061\end{array}$ & $\begin{array}{l}\text { 16b. } 449 \\
174.936\end{array}$ & $\begin{array}{l}24.21 \\
24.29\end{array}$ & $\begin{array}{l}0.050 \\
0.050\end{array}$ \\
\hline 5) & Endcap. 1 & $\mathrm{Ti}-6 \mathrm{Al} 4 \mathrm{~V}$ & 10. 291 & 0.00 & 0.320 \\
\hline 7) & Endcap. 2 & Ti - 6Al 4V & 10. 286 & 0.00 & 0.320 \\
\hline 9) & Buf f er & ZRO2 & 1. 825 & 7. 80 & 0.800 \\
\hline 10) & Ther mHol der & $\mathrm{AL}-6061$ & 176. 000 & 0.00 & 0.060 \\
\hline 11) & Ther $\mathrm{m}$ & $\mathrm{Si} C(I r r)$ & 4. 974 & 3. 50 & 0.900 \\
\hline 12) & Spri ng. 1 & I nconel & 15. 983 & 13. 57 & 0.925 \\
\hline 14) & Spri ng. 2 & I nconel & 15.866 & 13. 53 & 0.925 \\
\hline 16) & Spri ng. 3 & I nconel & 15. 953 & 13. 56 & 0.925 \\
\hline
\end{tabular}




\section{Specimen 7, 330C, EOI ANSYS Results}

\section{BOUNDARY CONDI TI ONS}

$\begin{aligned} \text { Heat transf er coef } \mathrm{fici} \text { ent } & =47100 . \mathrm{W} \mathrm{m} \mathrm{m}^{\circ}{ }^{\circ} \mathrm{C} \\ \text { Bul } \mathrm{k} \text { cool ant temperat ure } & =52.0{ }^{\circ} \mathrm{C}\end{aligned}$

\section{HEAT GENERATI ON}

\begin{tabular}{|c|c|c|c|c|}
\hline Part & Mat er i al & $\begin{array}{l}\text { Heat Gen. } \\
\text { GM dpl ane } \\
(\mathrm{W} \text { kg) }\end{array}$ & (WM dpl ane & $\begin{array}{c}\text { Load } \ldots \text {. } \\
\text { ( ocot i on } \\
\text { (W) }\end{array}$ \\
\hline $\begin{aligned} & \text { 1) } \text { Housi ng } \\
& \text { 3) } \text { Hol der } \\
& \text { 5) } \text { Endcap. } 1 \\
& \text { 7) } \text { Endcap. } 2 \\
& \text { 9) } \text { Buf f er } \\
& \text { 10) } \text { Ther nHol der } \\
& \text { 11) } \text { Ther m } \\
& \text { 12) } \text { Spr i ng. 1 } \\
& \text { 14) Spr i ng. } 2 \\
& \text { 16) Spri ng. 3 }\end{aligned}$ & $\begin{array}{l}\text { AL- 6061 } \\
\text { AL- 6061 } \\
\text { Ti- -6Al 4V } \\
\text { Ti -6Al 4V } \\
\text { ZRO2 } \\
\text { AL- } 6061 \\
\text { Si C(I rr }) \\
\text { I nconel } \\
\text { I nconel } \\
\text { I nconel }\end{array}$ & $\begin{array}{l}32500 . \\
32500 . \\
35200 . \\
35200 . \\
52000 . \\
32500 . \\
32900 . \\
39300 . \\
39300 . \\
39300 .\end{array}$ & $\begin{array}{r}129.4 \\
172.1 \\
22.5 \\
22.5 \\
94.7 \\
10.4 \\
4.2 \\
7.3 \\
7.4 \\
125.1\end{array}$ & $\begin{array}{r}128.9 \\
171.7 \\
22.4 \\
22.3 \\
94.5 \\
10.4 \\
4.2 \\
7.3 \\
7.4 \\
124.9\end{array}$ \\
\hline & & & 595.6 & 593. 9 \\
\hline
\end{tabular}

\section{CAPSULE TEMPERATURE SUMMARY}

\begin{tabular}{|c|c|c|c|c|c|c|c|}
\hline Name & & Materi al & Tavg & Tm n & $\operatorname{Tn} \operatorname{tax}$ & T. 025 & T. 975 \\
\hline 1) & Housi ng & AL- 6061 & 58. & 53. & 61. & 53. & 60. \\
\hline $\begin{array}{l}\text { 3) } \\
5)\end{array}$ & $\begin{array}{l}\text { Hol der } \\
\text { Endcap. } 1\end{array}$ & $\begin{array}{l}\text { AL- } 6061 \\
\mathrm{Ti}-6 \mathrm{Al} 4 \mathrm{~V}\end{array}$ & $\begin{array}{l}140 . \\
189 .\end{array}$ & $\begin{array}{l}135 . \\
156 .\end{array}$ & $\begin{array}{l}144 . \\
215 .\end{array}$ & $\begin{array}{l}136 . \\
165 .\end{array}$ & $\begin{array}{l}144 . \\
212 .\end{array}$ \\
\hline 7) & Endcap. 2 & $\mathrm{Ti}-6 \mathrm{Al} 4 \mathrm{~V}$ & 189. & 156. & 215. & 166. & 212. \\
\hline 9) & $\begin{array}{l}\text { Buf f er } \\
\text { Ther }\end{array}$ & $\mathrm{ZRO2}$ & 199. & 146. & 256. & 170. & 229. \\
\hline $\begin{array}{l}\text { 10) } \\
11)\end{array}$ & $\begin{array}{l}\text { Ther mHol der } \\
\text { Ther m }\end{array}$ & $\begin{array}{l}\text { AL- } 6061 \\
\text { Si C(I rr) }\end{array}$ & $\begin{array}{l}340 . \\
376 .\end{array}$ & $\begin{array}{l}337 . \\
366 .\end{array}$ & $\begin{array}{l}344 . \\
388 .\end{array}$ & $\begin{array}{l}338 . \\
371 .\end{array}$ & $\begin{array}{l}344 . \\
383 .\end{array}$ \\
\hline 12$)$ & Spr i ng. 1 & Inconel & 329. & 318. & & 322 & 335. \\
\hline 14) & Spr i ng. 2 & I nconel & 320. & 311. & 329. & 312 & \\
\hline 16) & Spri ng. 3 & I nconel & 326. & 311. & 339. & 316. & 33 \\
\hline
\end{tabular}

PROPERTY SUMMARY AT THE AVERAGE PART TEMPERATURE

$\begin{aligned} & \text { 1) } \text { Housi ng } \\ & \text { 3) } \text { Hol der } \\ & \text { 5) } \text { Endcap. } 1 \\ & \text { 7) } \text { Endcap. } 2 \\ & \text { 9) } \text { Buf fer } \\ & \text { 10) } \text { Ther } \text { mol der } \\ & \text { 11) } \text { Ther m } \\ & \text { 12) } \text { Spr i ng. } 1 \\ & \text { 14) Spri ng. } 2 \\ & \text { 16) Spri ing. } 3\end{aligned}$

\begin{tabular}{|c|c|c|c|}
\hline Mater i al & $\begin{array}{l}\text { Ther mal } \\
\text { Cond. } \\
\text { ( } \mathrm{W} \mathrm{m} \text { o } \mathrm{C})\end{array}$ & $\begin{array}{l}\text { Ther mal } \\
\text { Exp. } \\
\text { Coef } f \\
\left(\mu \mathrm{m} \mathrm{m}^{\circ} \mathrm{C}\right)\end{array}$ & $\begin{array}{c}\text { Eni s } \\
(\text { - - - ) }\end{array}$ \\
\hline L- 6061 & 166. 450 & 24. 21 & 0.050 \\
\hline AL- 6061 & 174.953 & 24.29 & 0.050 \\
\hline $\mathrm{Ti}-6 \mathrm{Al} 4 \mathrm{~V}$ & 10. 294 & 0.00 & 0.320 \\
\hline $\mathrm{Ti}-6 \mathrm{Al} 4 \mathrm{~V}$ & 10. 290 & & 0.320 \\
\hline $1-6061$ & & & \\
\hline AL- 6061 & 176. 00 & 0.00 & 0. 059 \\
\hline $\begin{array}{l}\text { Si C(I rr r) } \\
\text { I nconel }\end{array}$ & $\begin{array}{r}4.976 \\
15.885\end{array}$ & $\begin{array}{r}\text { 3. } 48 \\
13.54\end{array}$ & $\begin{array}{l}0.900 \\
0.925\end{array}$ \\
\hline & & & 0.925 \\
\hline & & 13. 53 & 0.925 \\
\hline
\end{tabular}




\section{Specimen 8, 330C, BOI ANSYS Results}

\section{BOUNDARY CONDI TI ONS}

Heat transfer coef $\mathrm{fici}$ ent $=47100 . \mathrm{W} \mathrm{na} \cdot{ }^{\circ} \mathrm{C}$

Bul $\mathrm{k} \mathrm{cool} \mathrm{ant} \mathrm{temperat} \mathrm{ure}=52.0^{\circ} \mathrm{C}$

\section{HEAT GENERATI ON}

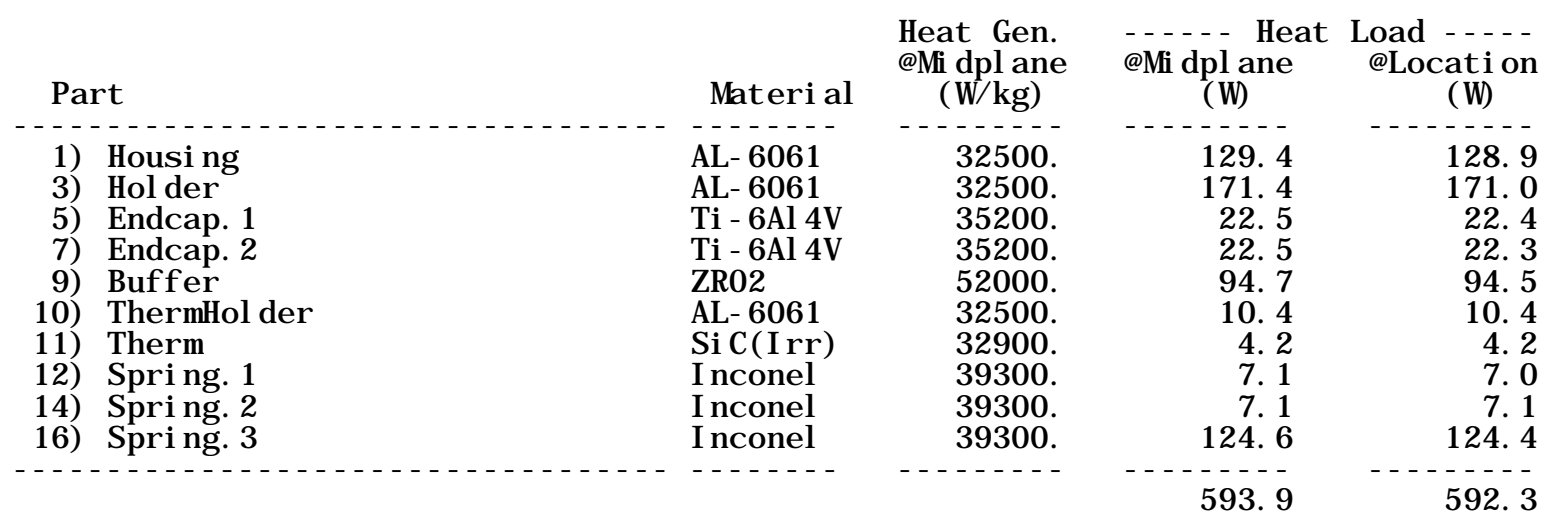

CAPSULE TEMPERATURE SUMMARY

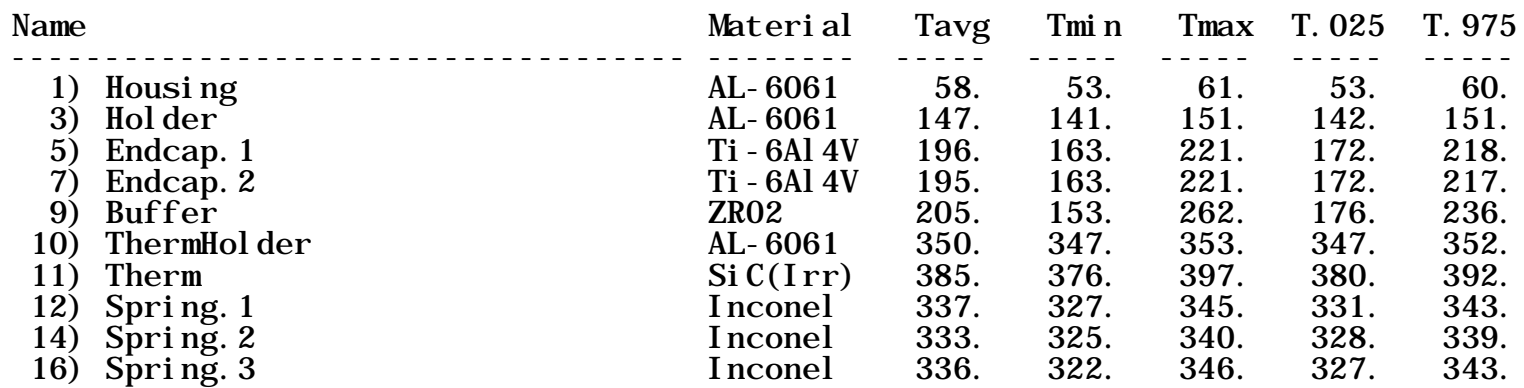

PROPERTY SUMMARY AT THE AVERAGE PART TEMPERATURE

\begin{tabular}{|c|c|c|c|c|c|}
\hline Name & & Mat er i al & 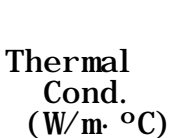 & $\begin{array}{l}\text { Ther mal } \\
\text { Exp. } \\
\text { Coef } \mathrm{f} \\
\left(\mu \mathrm{m} \text { ' }{ }^{\circ} \mathrm{C}\right)\end{array}$ & $\begin{array}{l}\text { Emi s } \\
(---) \text {. }\end{array}$ \\
\hline & Housing & & & & \\
\hline 1) & Hol der & $\begin{array}{l}A L-6061 \\
A L-6061\end{array}$ & $\begin{array}{l}\text { 166. } 448 \\
175.555\end{array}$ & $\begin{array}{l}\text { 24. } 21 \\
24.33\end{array}$ & $\begin{array}{l}0.050 \\
0.050\end{array}$ \\
\hline 5) & Endcap. 1 & Ti - 6Al 4V & 10.417 & 0.00 & 0.320 \\
\hline 7) & Endcap. 2 & $\mathrm{Ti}-6 \mathrm{Al} 4 \mathrm{~V}$ & 10. 411 & 0.00 & 0.320 \\
\hline 9) & Buf f er & ZRO2 & 1. 827 & 7. 80 & 0.800 \\
\hline 10) & Ther mol der & AL- 6061 & 176. 000 & 0.00 & 0.060 \\
\hline 11) & Ther $\mathrm{m}$ & $\mathrm{Si} C(I r r)$ & 4. 974 & 3. 51 & 0.900 \\
\hline 12) & Spring. 1 & I nconel & 16. 000 & 13. 58 & 0.925 \\
\hline 14) & Spr i ng. 2 & I nconel & 15. 945 & 13. 56 & 0.925 \\
\hline 16) & Spri ng. 3 & I nconel & 15. 983 & 13. 57 & 0.925 \\
\hline
\end{tabular}




\section{Specimen 8, 330C, EOI ANSYS Results}

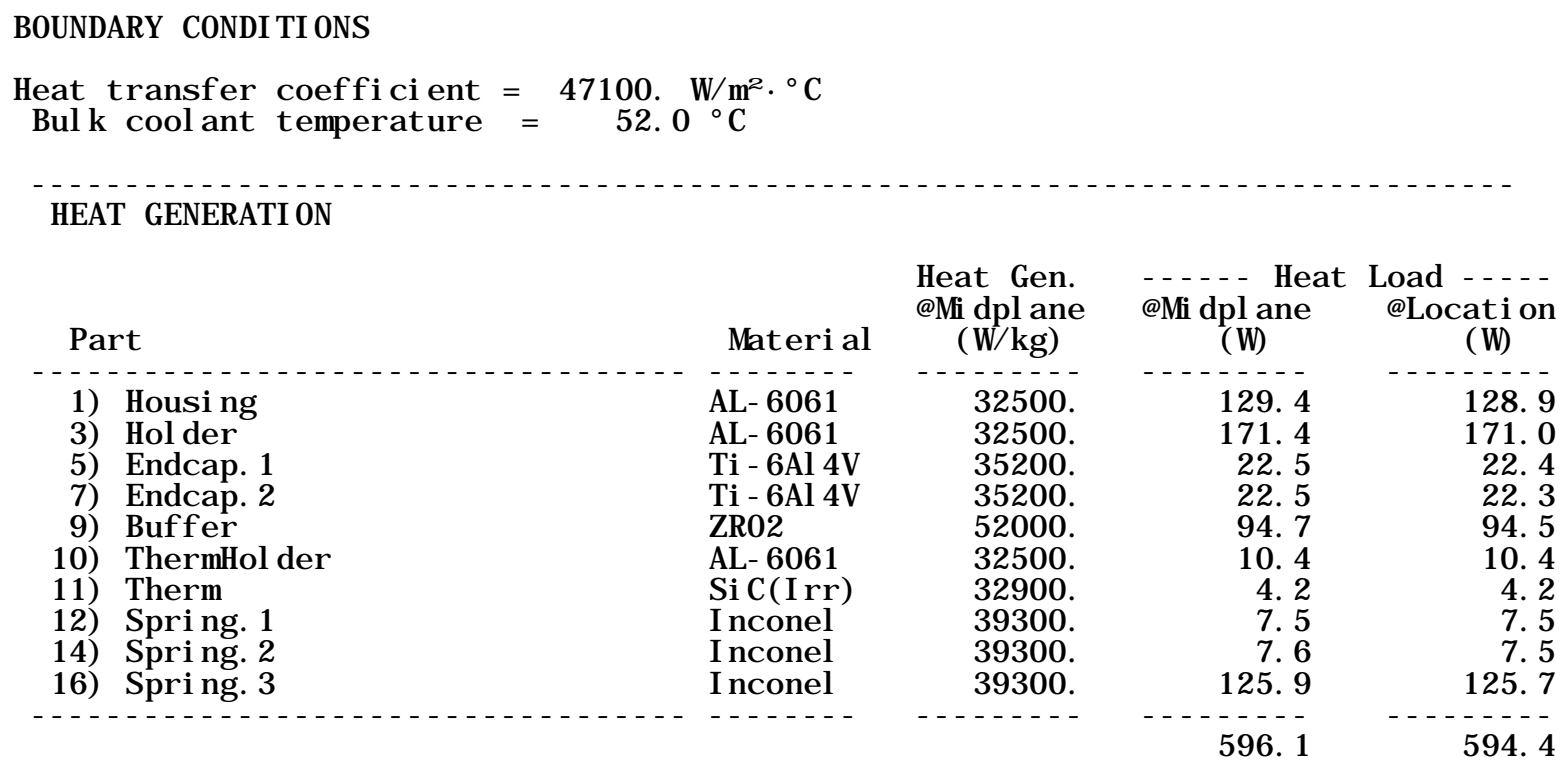

CAPSULE TEMPERATURE SUMMARY

\begin{tabular}{|c|c|c|c|c|c|c|c|}
\hline \multicolumn{2}{|c|}{ Name } & \multirow{2}{*}{ Mat eri al } & \multirow{2}{*}{$\begin{array}{l}\text { Tavg } \\
-. .--\end{array}$} & \multirow{2}{*}{$\begin{array}{r}\text { Tmin } n \\
-\end{array}$} & \multirow{2}{*}{$\begin{array}{r}\text { Thax } \\
-\end{array}$} & \multirow{2}{*}{ T. 025} & T. 975 \\
\hline \multicolumn{2}{|c|}{ - } & & & & & & \\
\hline \multirow{3}{*}{$\begin{array}{l}\text { 1) } \\
\text { 5) } \\
7)\end{array}$} & $\begin{array}{l}\text { Housl ng } \\
\text { Hol der }\end{array}$ & $\begin{array}{l}A L-6061 \\
A L-6061\end{array}$ & $\begin{array}{l}58 . \\
147 .\end{array}$ & $\begin{array}{l}53 . \\
142 .\end{array}$ & $\begin{array}{l}61 . \\
152 .\end{array}$ & $\begin{array}{l}53 . \\
143 .\end{array}$ & $\begin{array}{l}60 . \\
151 .\end{array}$ \\
\hline & Endcap. 1 & Ti - 6Al 4V & 196. & 163. & 221. & 172. & 218. \\
\hline & Endcap. 2 & $\mathrm{Ti}-6 \mathrm{Al} 4 \mathrm{~V}$ & 196. & 163. & 221. & 172. & 218. \\
\hline \multirow{4}{*}{$\begin{array}{r}9) \\
10) \\
11) \\
12)\end{array}$} & Buf f er & ZRO2 & 206. & 154. & 266. & 177. & 236. \\
\hline & Ther mHol der & $A L-6061$ & 339. & 336. & 342. & 336. & 342. \\
\hline & Ther $\mathrm{m}$ & $\mathrm{Si} \mathrm{C}(I r r)$ & 375. & 365. & 387. & 369. & 382. \\
\hline & Spri ng. 1 & I nconel & 326. & 315. & 339. & 319. & 336. \\
\hline \multirow{2}{*}{$\begin{array}{l}14) \\
16)\end{array}$} & Spri ng. 2 & I nconel & 321. & 312. & 328. & 316. & 326. \\
\hline & Spri ng. 3 & I nconel & 323. & 309. & 334. & 314. & 331. \\
\hline
\end{tabular}

PROPERTY SUMMARY AT THE AVERAGE PART TEMPERATURE

1) Housi ng
3) Hol der
5) Endcap. 1
7) Endcap. 2
9) Buf f er
10) Ther nHol der
11) Ther m
12) Spri ng. 1
14) Spri ng. 2
16) Spri ng. 3

\begin{tabular}{|c|c|c|c|}
\hline vat eri al & $\begin{array}{l}\text { Ther nal } \\
\text { Cond. } \\
\text { (W } \mathrm{m} \cong \mathrm{C})\end{array}$ & $\begin{array}{l}\text { Ther mal } \\
\text { Exp. } \\
\text { Coef f } \\
\left(\text { und m }{ }^{\circ} \mathrm{C}\right)\end{array}$ & $\begin{array}{l}\text { Emi } s \\
(---)\end{array}$ \\
\hline & & (1) & 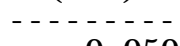 \\
\hline $\begin{array}{l}A L-6061 \\
A L-6061\end{array}$ & 166. 451 & 24. 21 & 0.050 \\
\hline $\begin{array}{l}\text { AL- 6061 } \\
\text { Ti - 6Al 4V }\end{array}$ & $\begin{array}{r}175.586 \\
10.423\end{array}$ & $\begin{array}{r}24.33 \\
0.00\end{array}$ & $\begin{array}{l}0.050 \\
0.320\end{array}$ \\
\hline Ti - 6Al 4V & 10.418 & 0.00 & 0.320 \\
\hline ZRO2 & 1.827 & 7. 80 & 0.800 \\
\hline AL- 6061 & 176.000 & 0.00 & 0.059 \\
\hline $\mathrm{Si} C(I r r)$ & 4. 976 & & 0.900 \\
\hline onol' & 15. 8 & 13. & 0.925 \\
\hline & & & 0.925 \\
\hline conel & 15.805 & 13. 51 & 0.925 \\
\hline
\end{tabular}

